\title{
Sustainability Reporting Future Study Using Scenario Planning Approach
}

\author{
Mohamad Kashanipour * \\ Associate Professor, Farabi Campus University of Tehran, Qom, Iran, \\ (Corresponding author), kashanipour@ut.ac.ir \\ Mohammad Reza Fathi \\ Assistant Professor, Farabi Campus University of Tehran, Qom, Iran \\ (reza.fathi@ut.ac.ir) \\ Omid Faraji \\ Assistant Professor, Farabi Campus University of Tehran, Qom, Iran \\ (omid_faraji@ut.ac.ir) \\ Mohamad Rahmani \\ Ph.D. Student, Farabi Campus University of Tehran, Qom, \\ Iran(Mrahmani71@ut.ac.ir)
}

\begin{abstract}
:
The economic, social and environmental implications of corporate activity have made sustainability reporting one of the challenging topics of accounting research. Given the impact of sustainability reporting on the continuity of future corporate activity, the present study was conducted as Sustainability Reporting Future Study Using Scenario Planning Approach. This study is mixed based on data. The present study was conducted in 1398. Initially, factors affecting sustainability reporting were extracted by reviewing the research background and interviewing 29 academic and professional experts. From 45 extracted factors, 20 factors were identified as significant factors based on expert questionnaire. Then, three factors were identified using cross-effects impact analysis and Mic Mac: legal requirements, climate and environmental crises, and the existence NGO as key drivers affecting future of sustainability reporting. Finally, according to the experts' opinions, four scenarios for the future of sustainability reporting were formulated and suggestions were made for each other.
\end{abstract}

Keywords: Sustainability, Future Study, Driver, Scenario Planning.

\section{Copyrights}

\section{(c) (1) $(2)$}

This license only allowing others to download your works and share them with others as long as they credit you, but they can't change them in any way or use them commercial. 


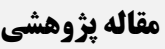

دوفصلنامه حسابدارى ارزشى و رفتارى- سال ينجم، شماره دهم، پاييز و زمستان 99 1 ا، صفحه9-1 • 1

\section{آينده يزوهى كزارشكرى يايدارى با به كار تيرى رويكر سناريونويسى

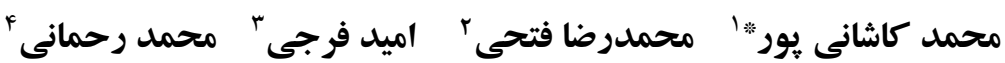

\author{
تاريخ پذيرش:99/II//T

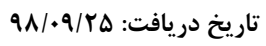

حكيله

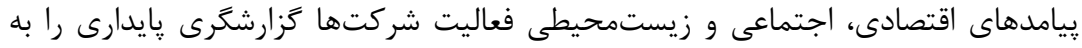
عنوان يكى از موضوعات جالث برانخيز تحقيقات حسابدارى مطرح ساخته است. با توجه به تاثير

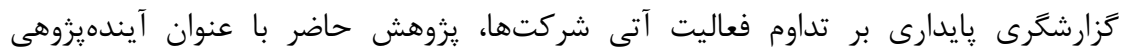

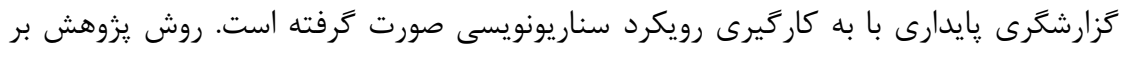

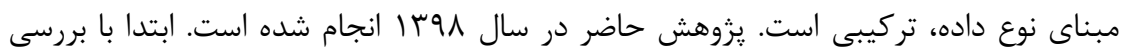

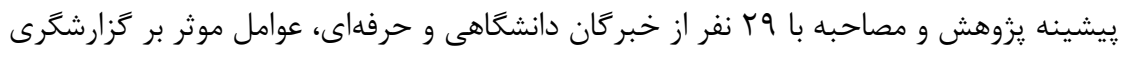

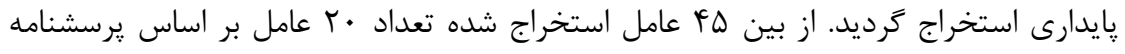
خبرهسنجى به عنوان عوامل معنادار شناسايى شدند. در ادامه با استفاده از پرسشنامه تحليل اثرات متقاطع و نرم افزار ميك مك سه عامل: الزامات قانونى، بحرانهاى آب و هوايى و زيست - مدان

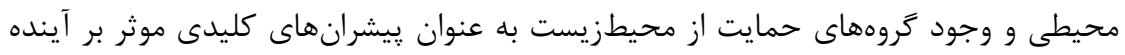

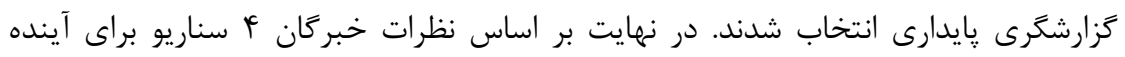

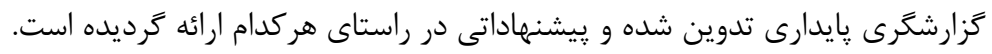

$$
\text { وازَّان كليدى: گزارشخرى يايدارى، آينده يزوهى، نيروى پيشران، سناريونويسى. }
$$

'دانشيار، دانشكده مديريت و حسابدارى، يرديس فارابى دانشعاه تهران (نويسنده مسئول) ، kashanipour@ut.ac.ir r reza.fathi@ut.ac.ir) استاديار، دانشكده مديريت و حسابدارى، يرديس فارابى دانشخاه تهران آاستاديار، دانشكده مديريت و حسابدارى، يرديس فارابى دانشعاه تهران (omid_faraji@ut.ac.ir)

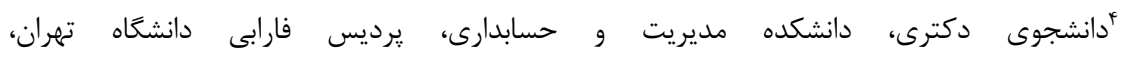

(Mrahmani71@ut.ac.ir) 
امروزه توجه به مسائل اجتماعى، اخلاقى و زيست محيطى در مجاورت مسائل اقتصادى براى ذينغعان شركت با اهميت شده است. يايدارى كسب و كار در حوزه مسائل مرتبط به مسئوليت

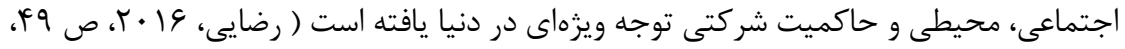

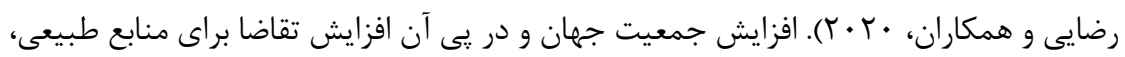

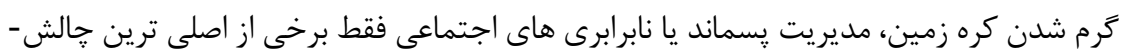

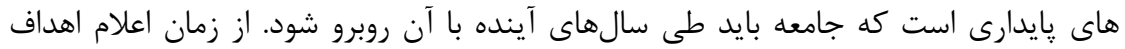

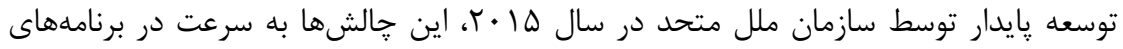

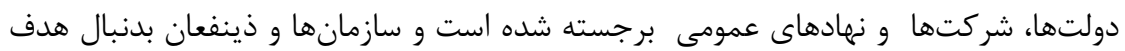
صرف در دستيابى به حداكثر كردن منافع اقتصادى نيستند. در نتيجه با توجه به نگرانى روزافزون

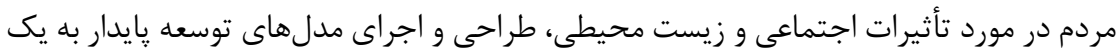

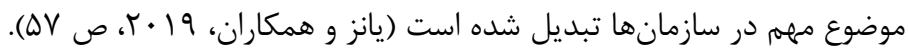

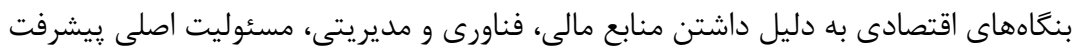
در مدلهاى توسعه يايدار' را بر عهده دارند. با اين حال، همه بازيخران جامعه به ويزه آنهايى كه

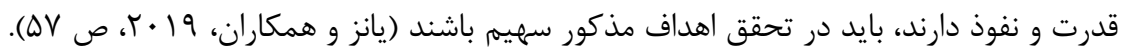

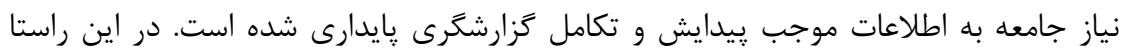
ذينفعان بر سازمانها فشار آوردهاند تا اطلاعات اجتماعى و زيست محيطى بيشترى را افشا كنند. در طرف مقابل نيز سازمانها به منظور حفظ منافع خود سعى دارند به توضيح اثرات اقتصادى، اجتماعى و زيست محيطى فعاليتهاى خود و نحوه برخورد با آنها بِردازند(ويليرس و مارون، 11 • r،ص (9). ليكن حسابدارى و گزارشگرى مالى سنتى به اندازه كافى نمىتواند نيازهاى

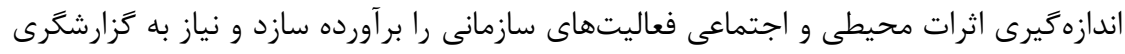

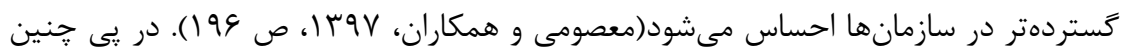
تقاضايى، جارجوبهاى افشاى اطلاعات پايدارى به وجود آمدند تا سازمانها بتوانند ادعا كنند

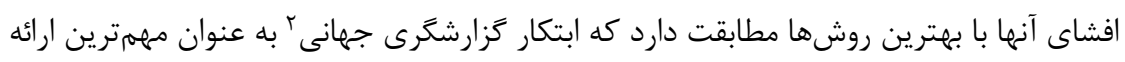

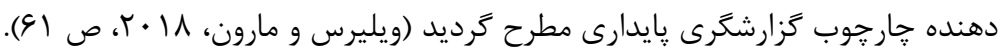

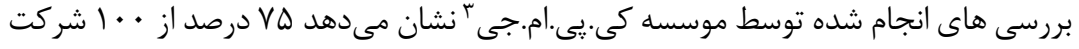

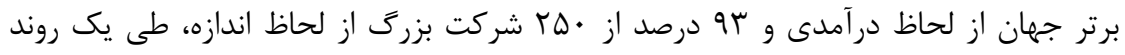

${ }^{1}$ Sustainable Development

${ }^{2}$ Global Reporting Initiative: GRI $3 \mathrm{KPMG}$ 


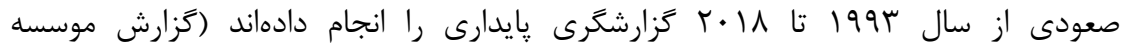

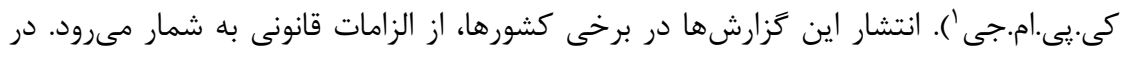

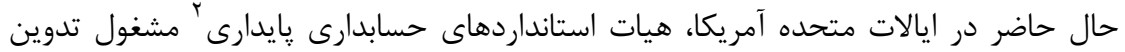

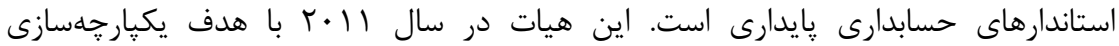

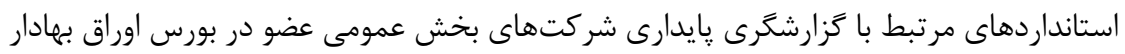

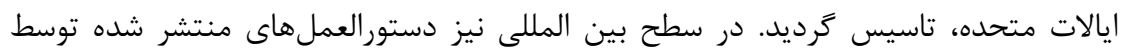

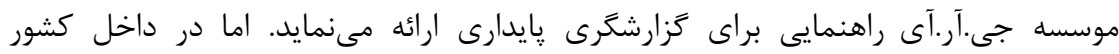

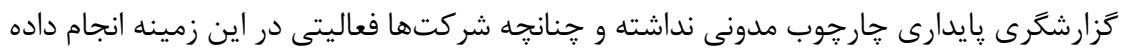

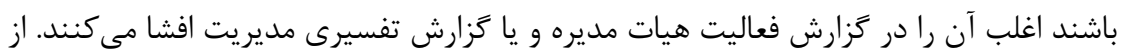
طرفى ديخر توجه به بحث مسئوليت اجتماعى شركتها و آلودگى هاى محيط زيست در كشور

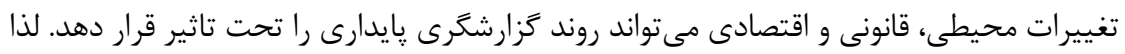

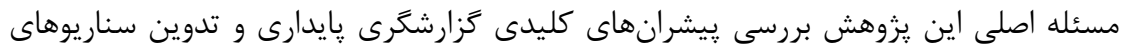

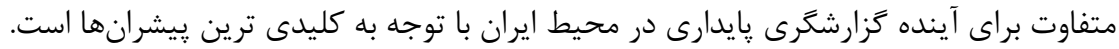

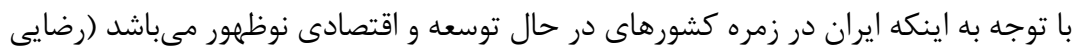

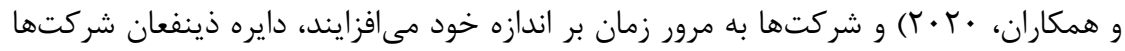
وسيعتر شده و توجهات بيشترى را تقاضا خواهند كرد. همجنين در زذر محيط اقتصادى ايران

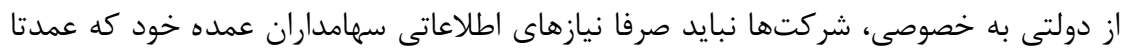

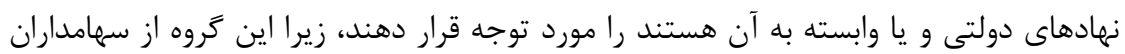
حتى در صورتى كه شركتها صورتهاى مالى منتشر نكنند نيز قادرند نيازهاى اطلاعاتى خود ران إنائ

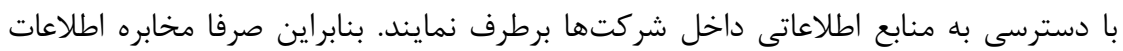

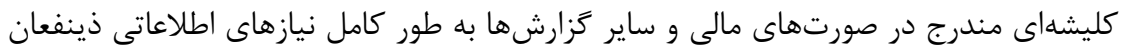
شركت را در حركت به سمت توسعه بايدار و رفاه اجتماعى برطرف نمى كند و اجزاء گزارشكرى

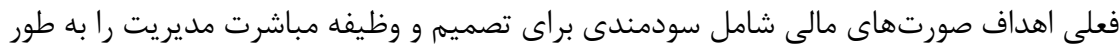

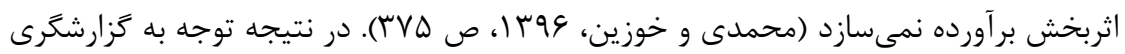

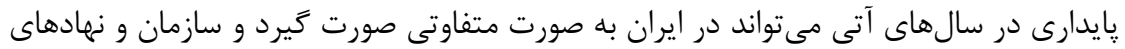

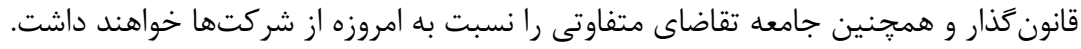

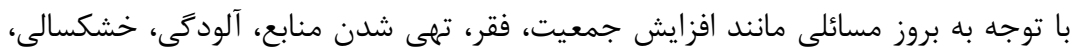
تغييرات جهانى آب و هوا، بيمارىهاى خطرناك و ... سازمانها بايد در تمام فعاليتهاى خرد و و

1 - http://gallery.cee.kpmg.com/HU/Newsletters/prezi/CSR_Reporting

2 - Sustainability Accounting Standard Board: SASB 
كلان خود در كنار توجه به سود، جامعه و محيطزيست را نيز در نظر بخيرند تا تلاش سازمانها

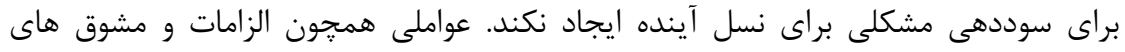

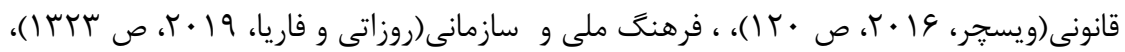

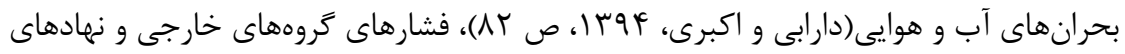

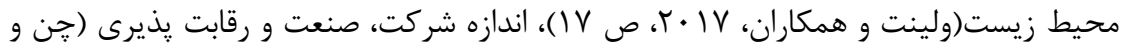

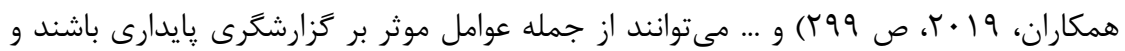
آينده آن را تحت تاثير قرار دهند. لذا شركتها بايد تلاش عمدهاى در اين زمينه داشته و نتايج

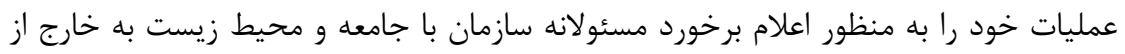

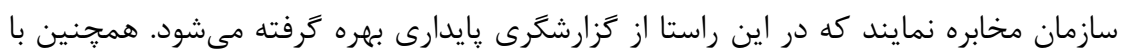

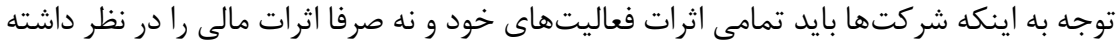

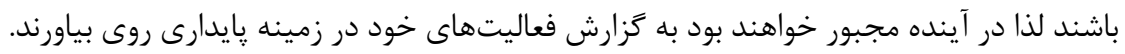

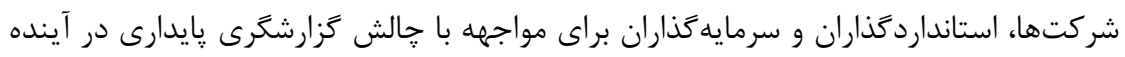

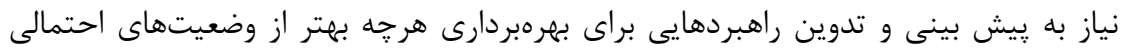

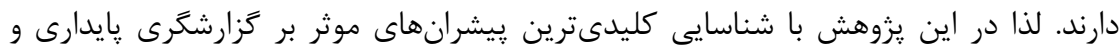

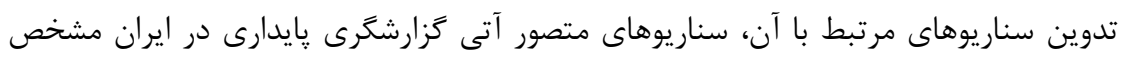

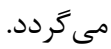

يزوهش حاضر اولين يزوهشى است كه با استفاده از روش آيندهيزوهى با رويكرد سناريونويسى

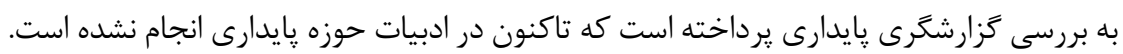

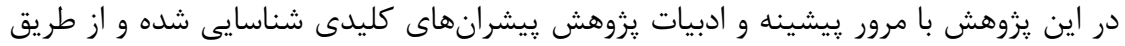

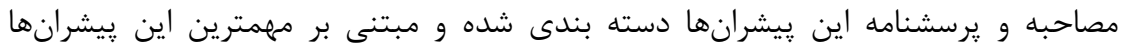

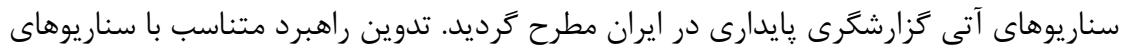

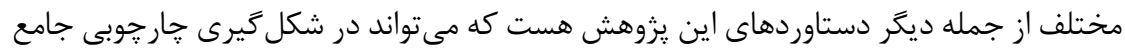
براى كزارشكرى يايدارى بسيار موثر باشد.

r-مبانى نظرى و ييشينه ويزوهش

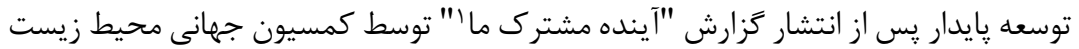

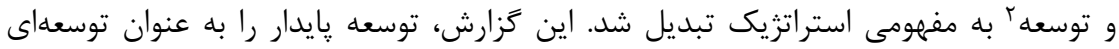

${ }^{1}$ Our Common Future

${ }^{2}$ World Commission on Environment and Development 
تعريف كرده است كه نيازهاى نسل فعلى را برآورده مى كند بدون آنكه توانايى نسل آينده را براى

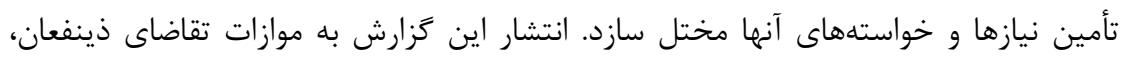

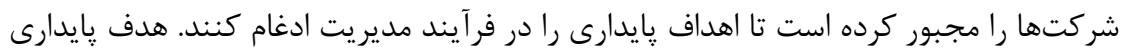
حفظ همبستكى اجتماعى، حفظ محيط زيست و اطمينان از توسعه اقتصادى به شكلى متعادل

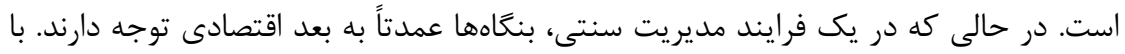

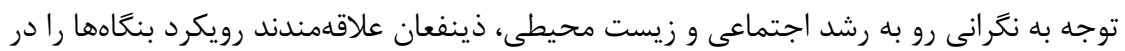

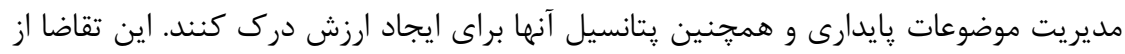

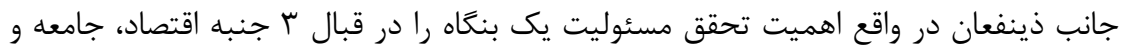

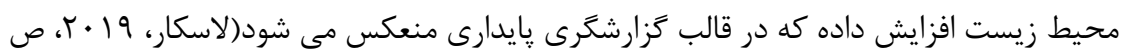
r). كزارش پايدارى كزارشى است كه توسط يك شركت يا سازمان در مورد اثرات اقتصادى،

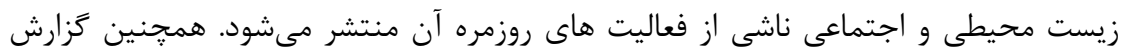

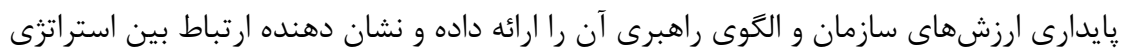

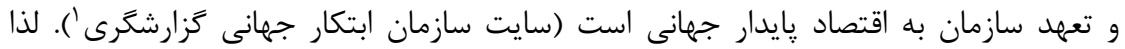

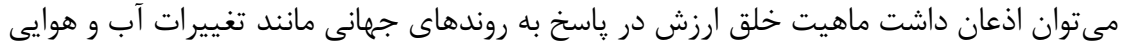

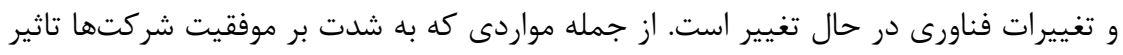

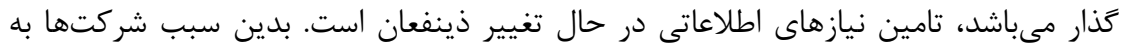

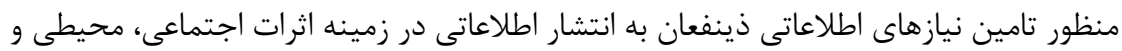

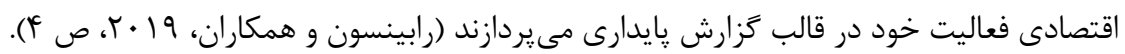

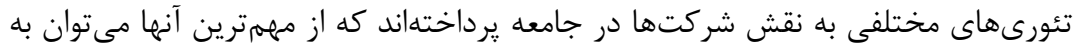

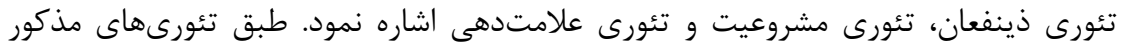

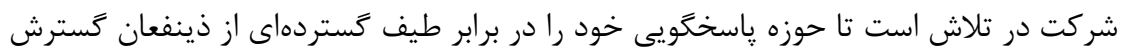

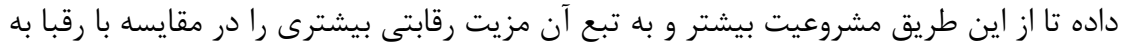

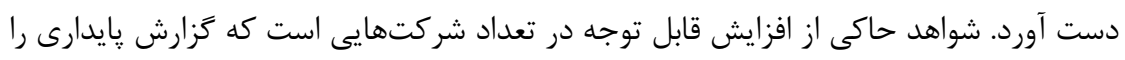

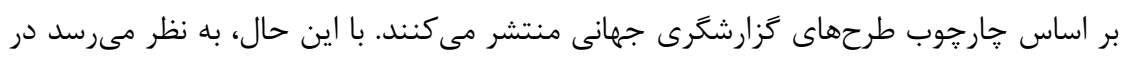

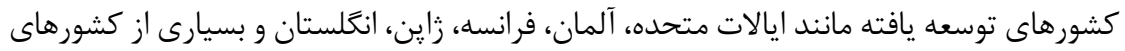

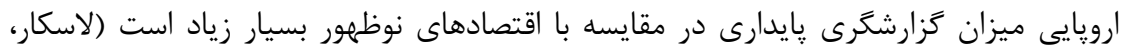

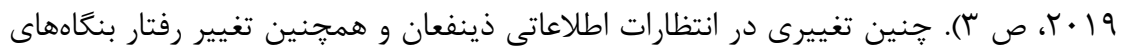

\footnotetext{
1 - https://www.globalreporting.org/information/sustainability-reporting
} 
اقتصادى نسبت به تحقق اهداف پايدار، موجب جلب توجه يزوهش ران به اين حوزه گرديده است.

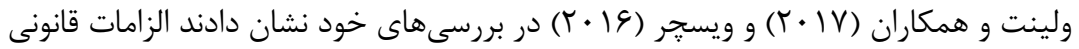
از مهممترين محركهاى زَارشكرى یايدارى و عملكرد مسئوليت اجتماعى شركتهاست.

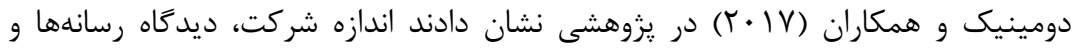

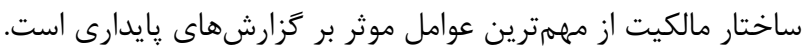
كازى و يار (T) (T) با بررسىهاى خود در مورد شركتهاى بورس استانبول به اين نتيجه

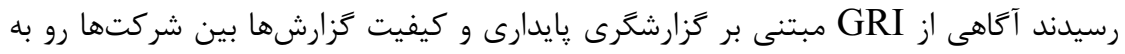

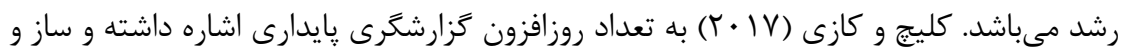
كارهاى حاكميت شركتى، كميتههاى يايدارى، نوع صنعت، اندازه شركت و سودآورى را از عوامل تعيين كننده گزارشخَى يايدارى دانستند.

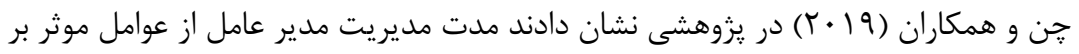

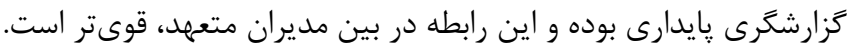

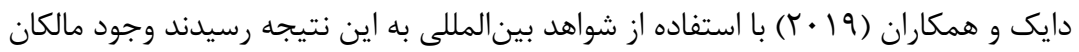
نهادى بر مسئوليت اجتماعى شركتها تاثير مثبتى دارد.

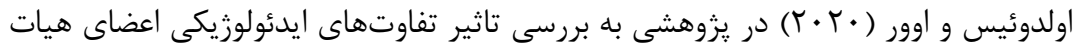

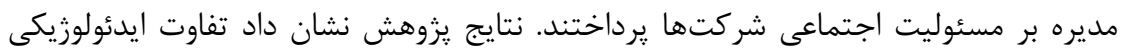
اعضاى هيات مديره تاثير منفى و معنادارى بر عملكرد مسئوليت اجتماعى شركتها متها دارد.

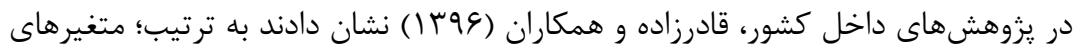
اندازه، اهرم مالى، مالكيت مديريتى، تمركز مالكيت، دو گانغَى مسئوليت مديرعامل، تورم، سابقه،

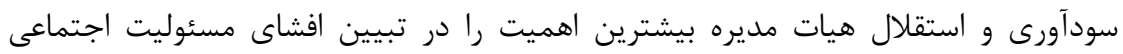
شركتها دارند. فخارى و همكاران (צو (1) در مطالعهاى نشان دادند افشاى اطلاعات راهبرى شركتى در ززارش هاى شركتهاى ايرانى روند صعودى داشته است؛ در حالى كه افشاى اطلاعات زيست محيطى و اجتماعى روند متغيرى داشته است. از نظر ايشان سطح پايين افشاى ابعاد زيست محيطى و اجتماعى در شر كتهاى ايرانى، نشان دهنده شكاف وضعيت موجود از انتظارات خبركان است.

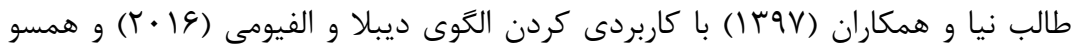
كردن آن با محيط ايران نشان دادند ابتدا نظام اخلاقى اسلامى، در مرحله دوم اصول تجارت 
اسلامى، سيس سامانه سود و زيان و در انتها مقررات حسابدارى و حسابرسى اسلامى داراى بيشترين ميزان اهميت است. سيت سمانه

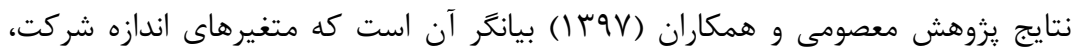

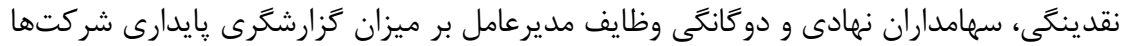
تأثير معنادارى دارند.

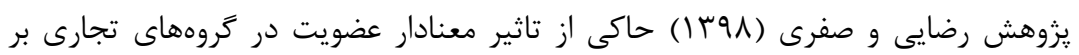

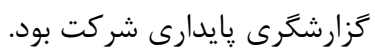

عبدالهزاده و امين (99جاן) نشان دادند نكَرش، هنجار ذهنى، كنترل رفتارى ادراك شده،

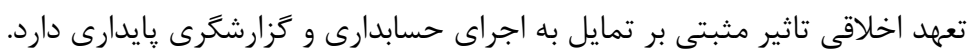

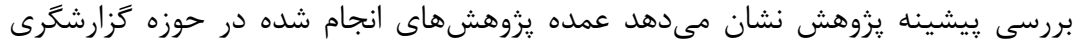

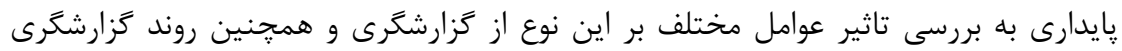

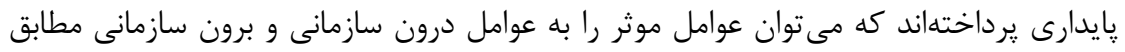

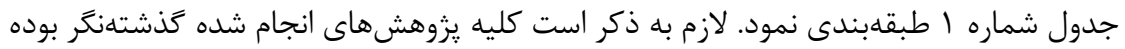

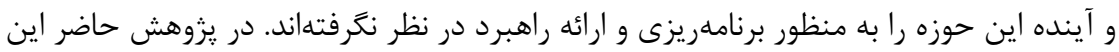

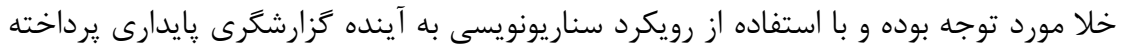

شد. - n

جدول(: طبقدبندى عوامل موثر بر كَارشكَرى بايدارى (مستخرج از يِيشنه يزوهش)

\begin{tabular}{|c|c|}
\hline عوامل برون سازمانى & عوامل درون سازمانى \\
\hline الزامات قانونى ( ملى يا بين المللى) & 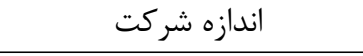 \\
\hline بحران هاى آب و هوايى و زيست محيطى & دانش و نكرش مديران شركت \\
\hline وجود كروه هاى حمايت از محيط زيست & ساختار مالكيت شركت \\
\hline مشوق هاى قانونى ( ملى يا بين المللى) & ويثخى هاى هيات مديره \\
\hline فرهنَ ملى كشور (ذينفع محور بودن كشور) & سازوكارهاى راهبرى شركتى \\
\hline فشار ذينفعان، نهادهاى حرفه اى، رسانهها & ويزگى هاى رفتارى مديران \\
\hline شاخص هاى اقتصادى كشور & نوع صنعت \\
\hline وجود نخرش و الزامات اسلامى & دانش و نكرش مديران شركت \\
\hline دولتى يا خصوصى بودن اقتصاد & فرهنَ سازمانى \\
\hline برَزارى همايش ها و انتشار مجلات تخصصى & شاخص هاى عملكردى شركت \\
\hline
\end{tabular}


ביא

\section{r-سوالات بزوهش}

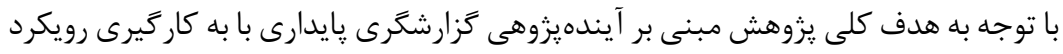

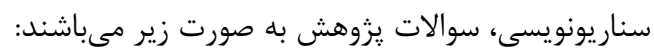

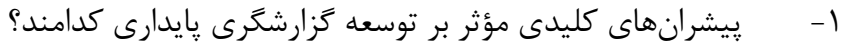

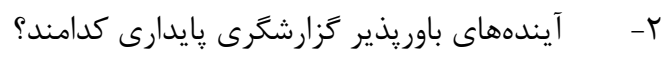

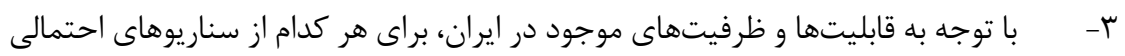

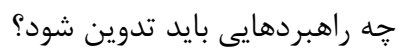

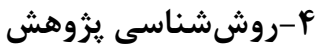

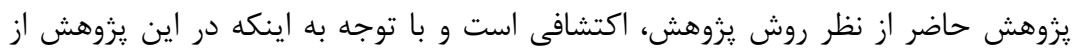

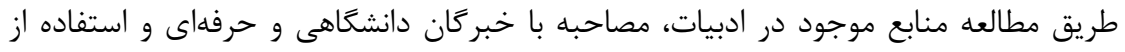

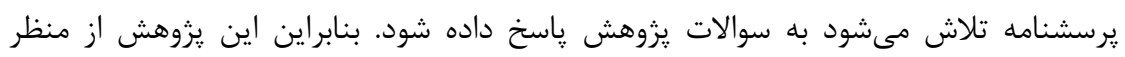

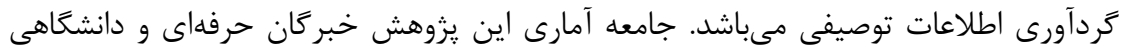

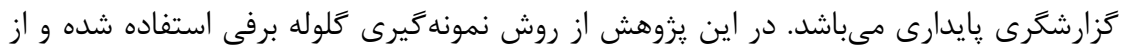

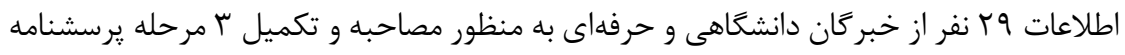

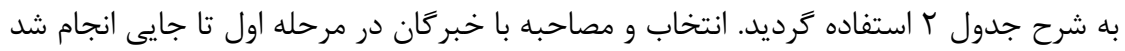

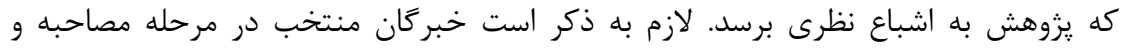

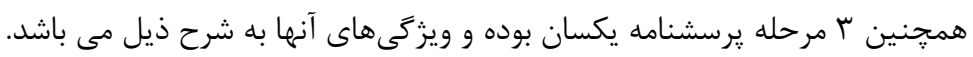
جدول r: اطلاعات جمعيت شناختى خبر كان ان ونان

\begin{tabular}{|c|c|c|c|c|c|c|}
\hline انتخاب & سابقه كار & سن (سال) & تعداد & تحصيلى آخدرى & جنسيت & حوزه \\
\hline \multirow{2}{*}{ فعاليت در حوزه كزارشكَرى } & r. & $i \wedge$ & $\Delta$ & دكترى & \multirow{2}{*}{ مرد } & \multirow{2}{*}{ حرفهاى } \\
\hline & IV & kq & F & كارشناسى ارشد & & \\
\hline \multirow{3}{*}{ 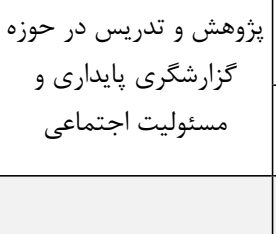 } & 9 & ra & 9 & دكترى & زن & \multirow{2}{*}{ دانشَاهى } \\
\hline & 1 & ru & If & دكترى & مرد & \\
\hline & if & f. & rq & \multicolumn{3}{|c|}{ جمع } \\
\hline
\end{tabular}


جهت انجام يزوهش كامهاى ذيل طى كرديد:

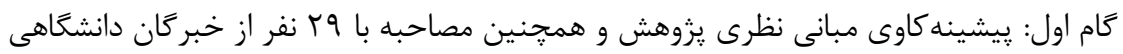

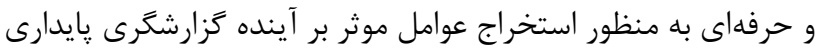

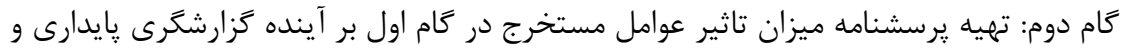

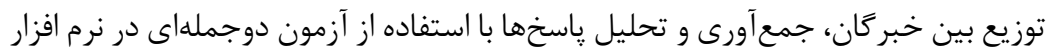
SPSS

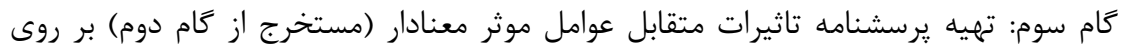

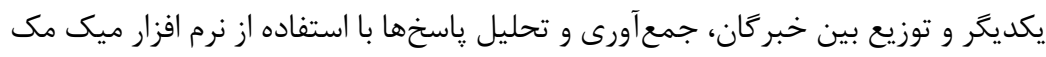

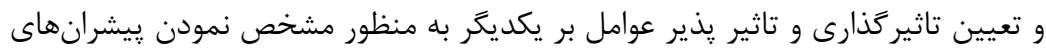

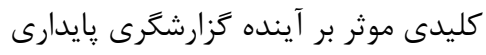

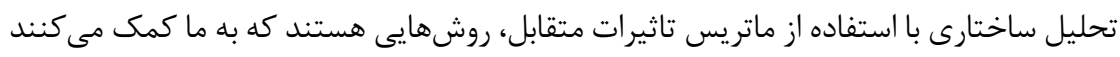

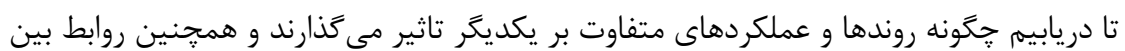

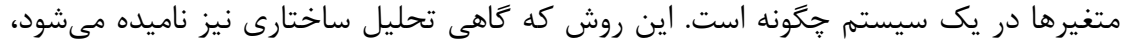

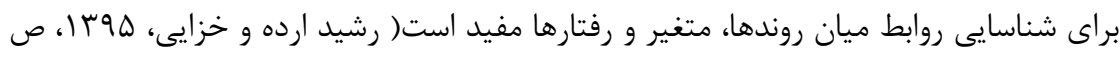
. ( $\mathrm{V}$.

نيروى پيشران، عناصرى هستند كه باعث حركت و تغيير در طرح اصلى سناريوها شده و سرانجام

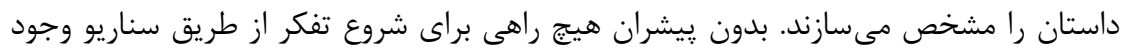

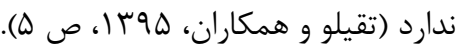
وضعيتهاى مختلفى كه متغيرها از لحاظ تاثيركذارى و تاثيريذيرى مىتوانند اختيار كنند به

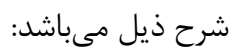
متغيرهاى تاثير كذار: اين متغيرها بيشتر تاثير كذار بوده و كمتر تاثيريذير از ساير عوامل مى باشندا.

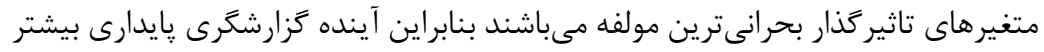
به اين متغيرها بستخى دارد.

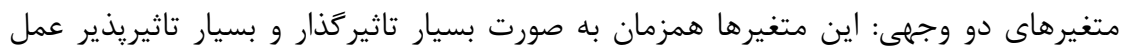

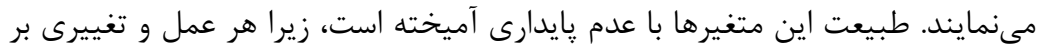

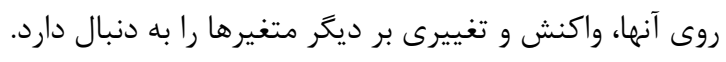

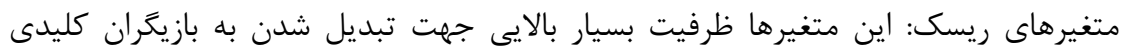

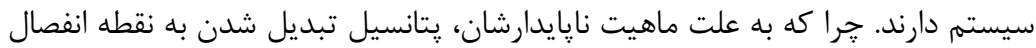

$$
\text { سيستم را دارا مى باشند. }
$$


متغيرهاى هدف: اين متغيرها بيش از آنكه تاثير كذار باشند، تاثيريذيرند. بنابراين آنها را مىتوان

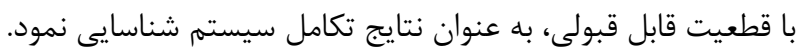

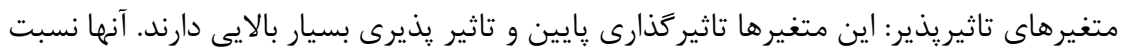

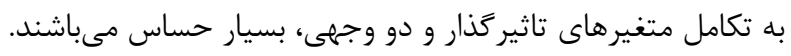

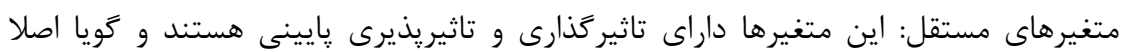

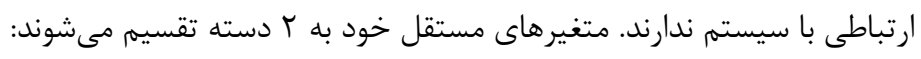

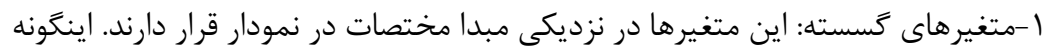

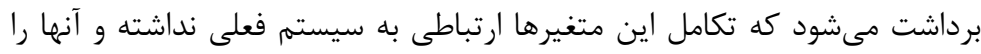

$$
\text { مى توان از سيستم خارج نمود. }
$$

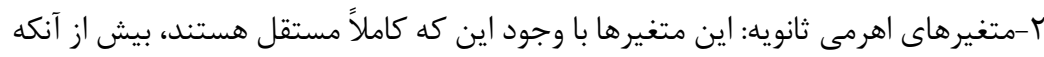

$$
\text { تاثيريذير باشند، تاثير تذارند. }
$$

متغيرهاى تنظيمى: اين متغيرها در نزديكى مركز ثقل نمودار قرار دارند. اين متغيرها مىتوانند

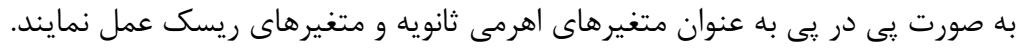

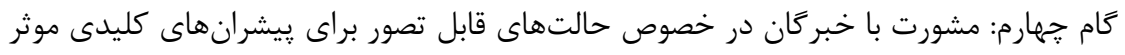

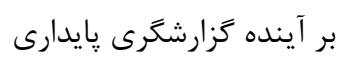

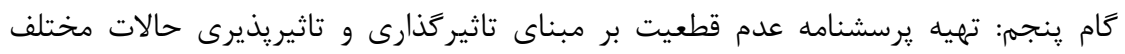

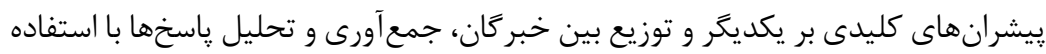

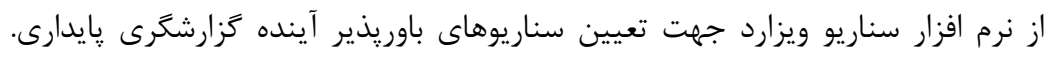

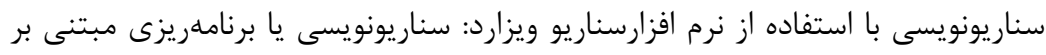

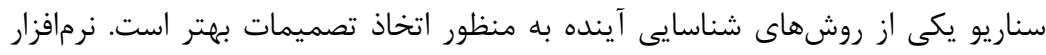

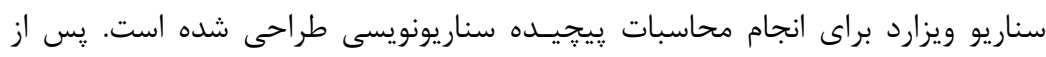

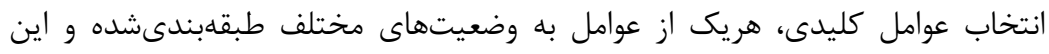

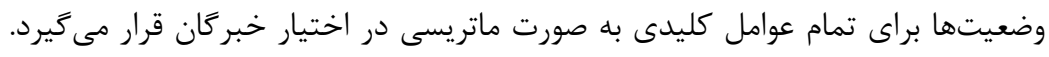

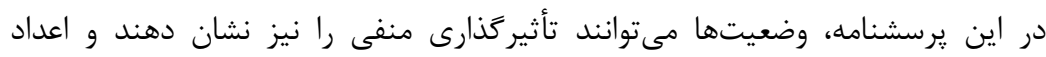

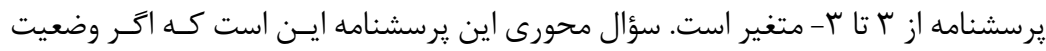

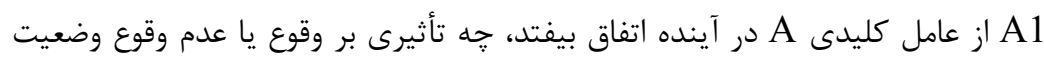

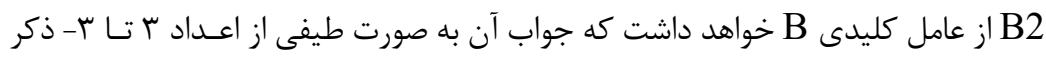

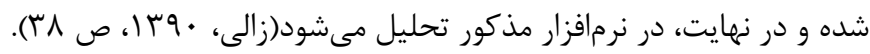

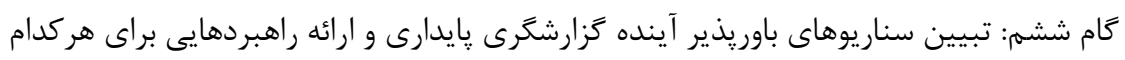
از آنها. 
همانكونه كه ذكر شد اين بزوهش شامل ؟ برسشنامه مىباشد كه به بررسى روايى و پايايى

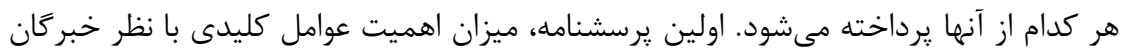

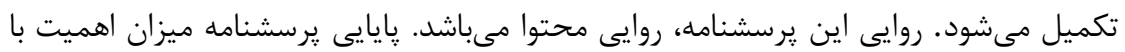

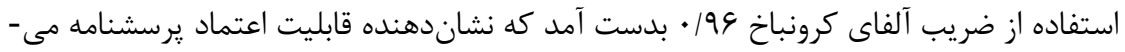

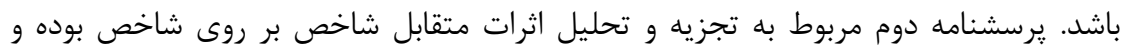

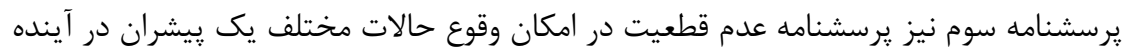

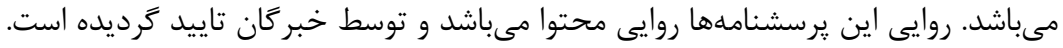

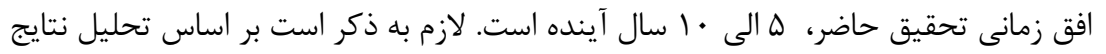

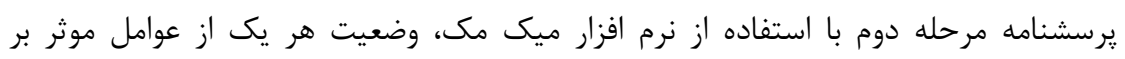

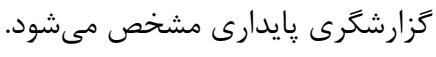

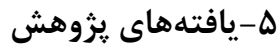

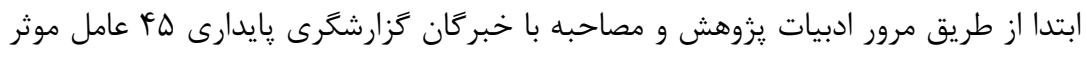

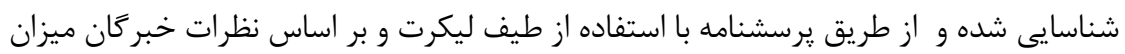

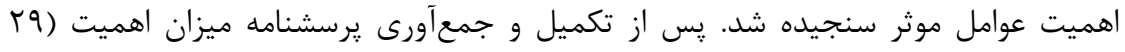

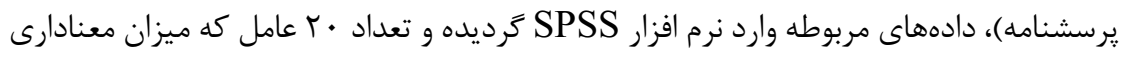

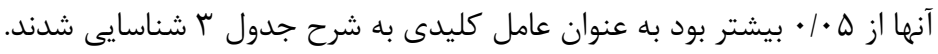

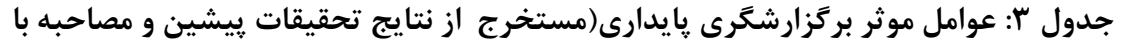
خبركان) - ( خان

\begin{tabular}{|c|c|c|}
\hline منبع & عامل & رديف \\
\hline 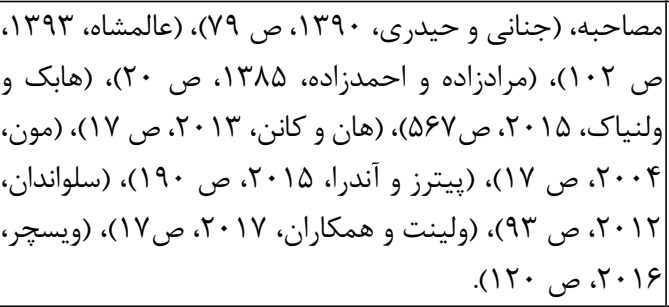 & $\begin{array}{c}\text { الزامات قانونى ( ملى يا بين } \\
\text { الملى) }\end{array}$ & 1 \\
\hline 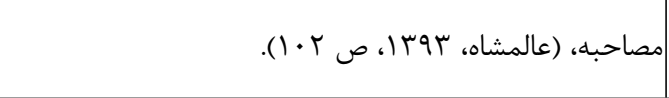 & مشوقهاى قانونى ( ملى يا & $r$ \\
\hline 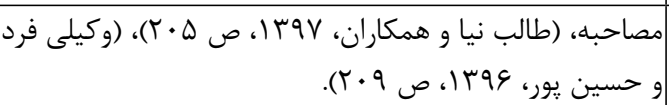 & وجود نكرش و الزامات اسلامى & r \\
\hline
\end{tabular}


دو فصلنامه حسابدارى ارزشى و رفتارى، سال ينجم، شماره دهم، پِاييز و زمستان وجسا

$\Lambda$.

\begin{tabular}{|c|c|c|}
\hline 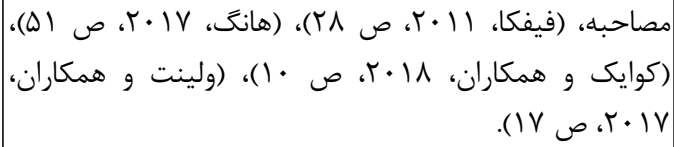 & 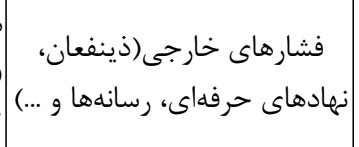 & F \\
\hline مصاحبه. & 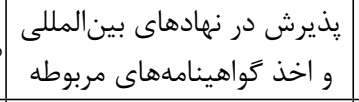 & $\Delta$ \\
\hline 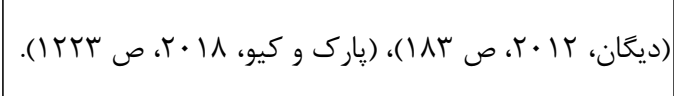 & وجود گروههاى حمايت از محيط زيست & $q$ \\
\hline \multirow[t]{3}{*}{ 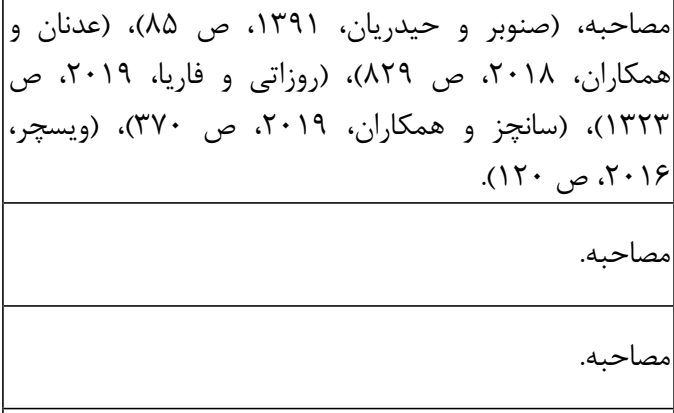 } & $\mid$ & $V$ \\
\hline & 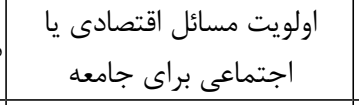 & $\wedge$ \\
\hline & 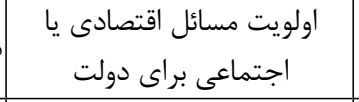 & 9 \\
\hline 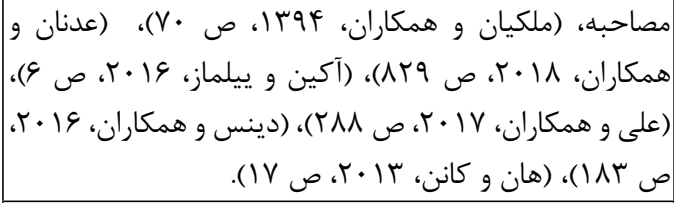 & |دولتى يا خصوصى بودن اقتصاد & $1 \cdot$ \\
\hline 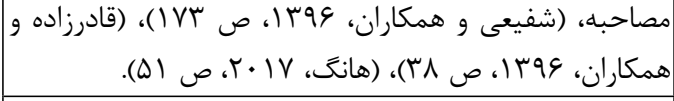 & شاخصهاى اقتصادى كشور & 11 \\
\hline 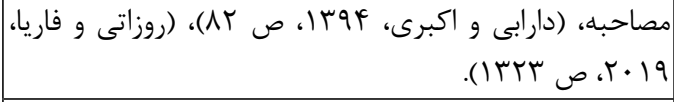 & بحرانهاى آب و هوايى و & ir \\
\hline 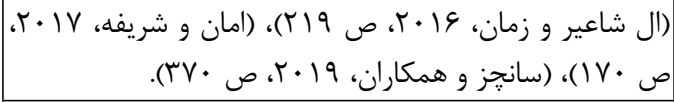 & تنوع جنسيتى هيات مديره & $1 \pi$ \\
\hline 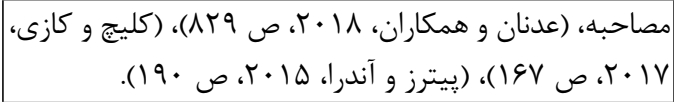 & 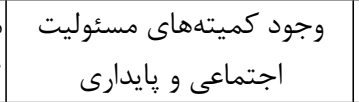 & If \\
\hline 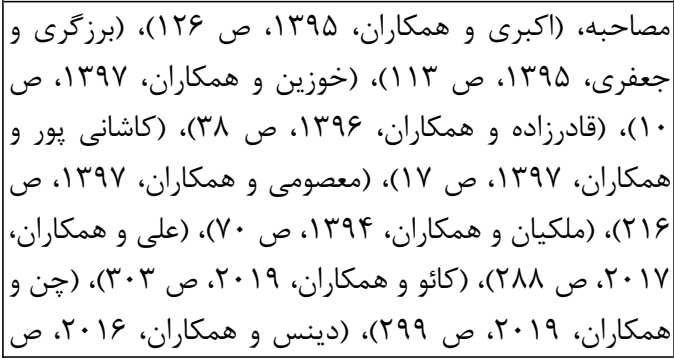 & اندازه شركت & 10 \\
\hline
\end{tabular}




\begin{tabular}{|c|c|c|}
\hline 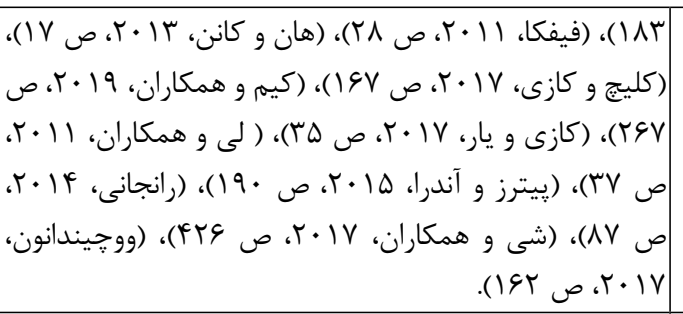 & & \\
\hline 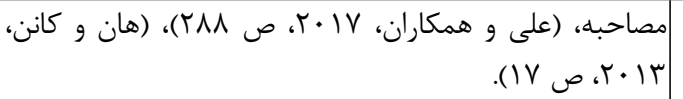 & شهرت شركت & 18 \\
\hline 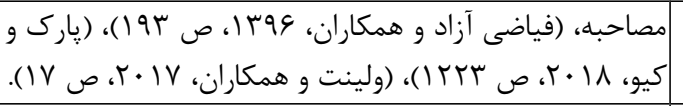 & رقابت & IV \\
\hline 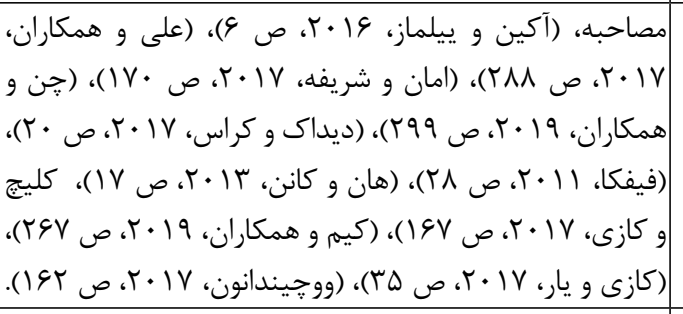 & نوع صنعت & 11 \\
\hline 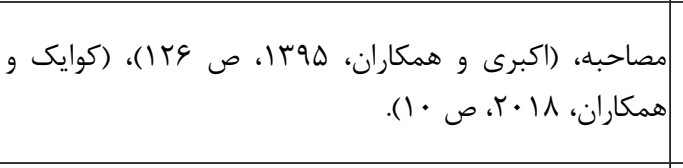 & 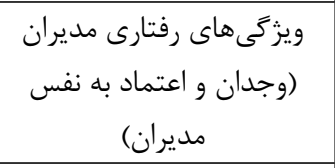 & 19 \\
\hline 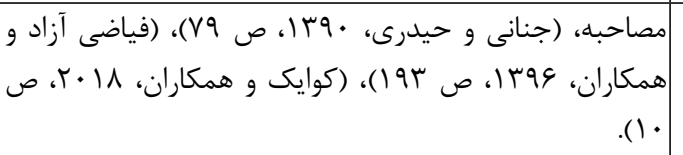 & دانش و نكرش مديران شركت & $r$. \\
\hline
\end{tabular}

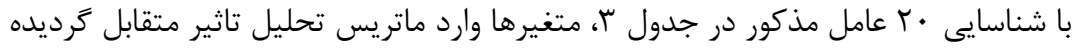

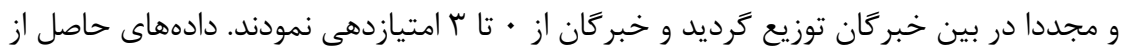

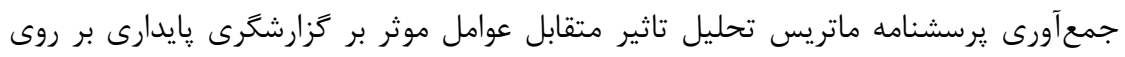

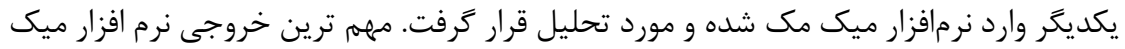

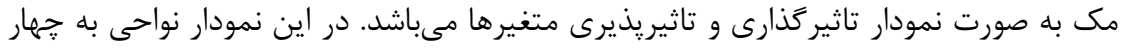

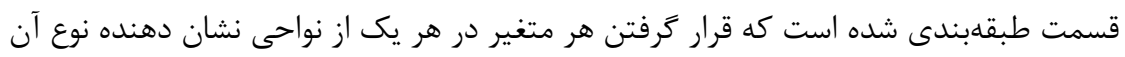

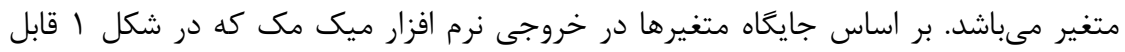

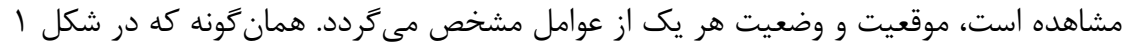

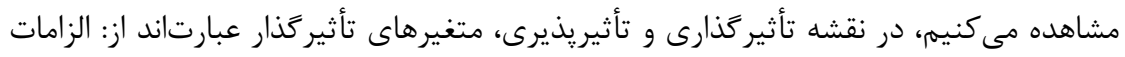

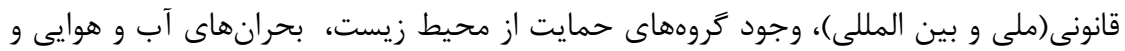


زيست محيطى. اين عوامل بيشترين تاثيركذارى بر ساير عوامل و در عين حارئ حال كمترين

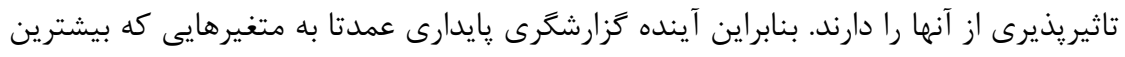

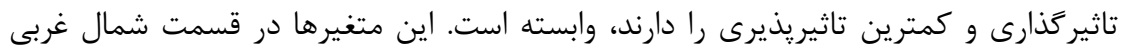

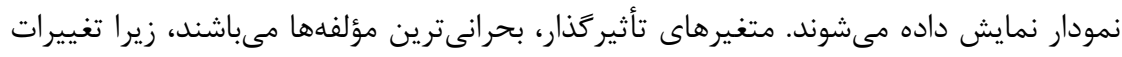

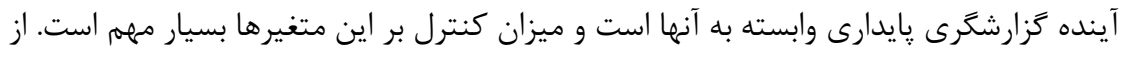

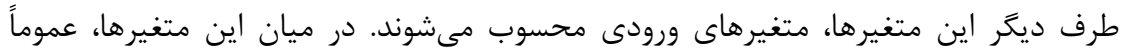

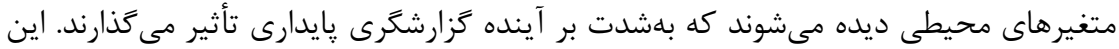

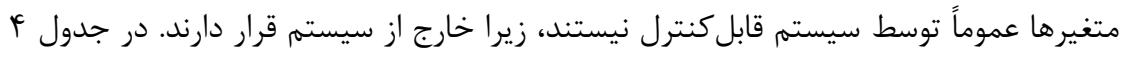

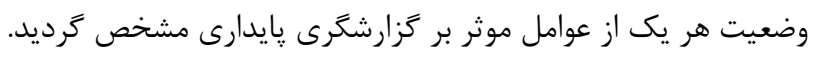

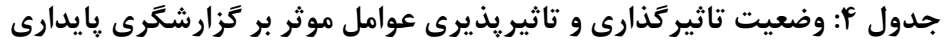

\begin{tabular}{|c|c|}
\hline متغير & نوع متغير \\
\hline بحران هاى آب و هوايى و زيست محيطي & \multirow{3}{*}{ تأثير حذار } \\
\hline وجود گروههاى حمايت از محيط زيست & \\
\hline الزامات قانونى (ملى و بين المللى) & \\
\hline اولويت مسائل اقتصادى و اجتماعى دولت & \multirow{5}{*}{ دو وجهى } \\
\hline اولويت مسائل اقتصادى و اجتماعى جامعه & \\
\hline مشوق هاى قانونى & \\
\hline فرهنَ ملى كشور & \\
\hline دولتى يا خصوصى بودن اقتصاد & \\
\hline يذيرش در نهادهاى بين المللى & \multirow{5}{*}{ 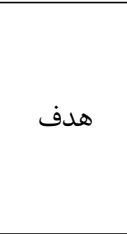 } \\
\hline شهرت شركت & \\
\hline فشارهاى خارجى (ذينفعان و ...) & \\
\hline شاخص هاى اقتصادى كشور & \\
\hline وجود كميته هاى مسئوليت اجتماعى و پايدارى & \\
\hline ويزگگى هاى رفتارى مديران & \multirow{2}{*}{ تأثير ريذير } \\
\hline 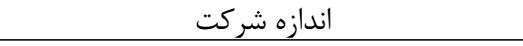 & \\
\hline دانش و نكَرش مديران شركت & \multirow{3}{*}{ 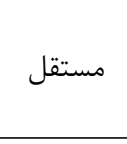 } \\
\hline وجود نكرش و الزامات اسلامى & \\
\hline تنوع جنسيتى هيئت مديره & \\
\hline نوع صنعت & 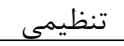 \\
\hline رقابت & 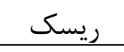 \\
\hline
\end{tabular}




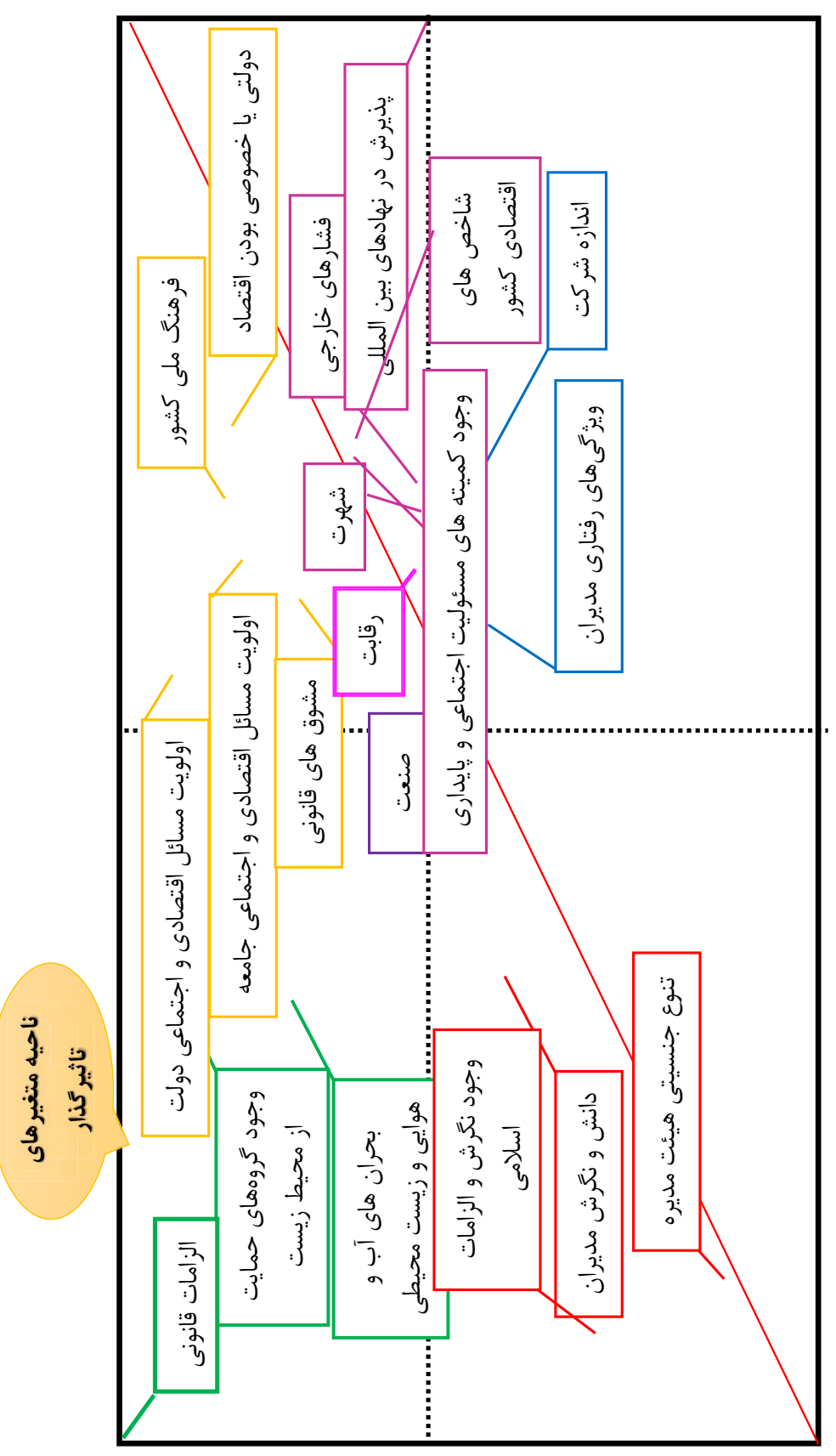




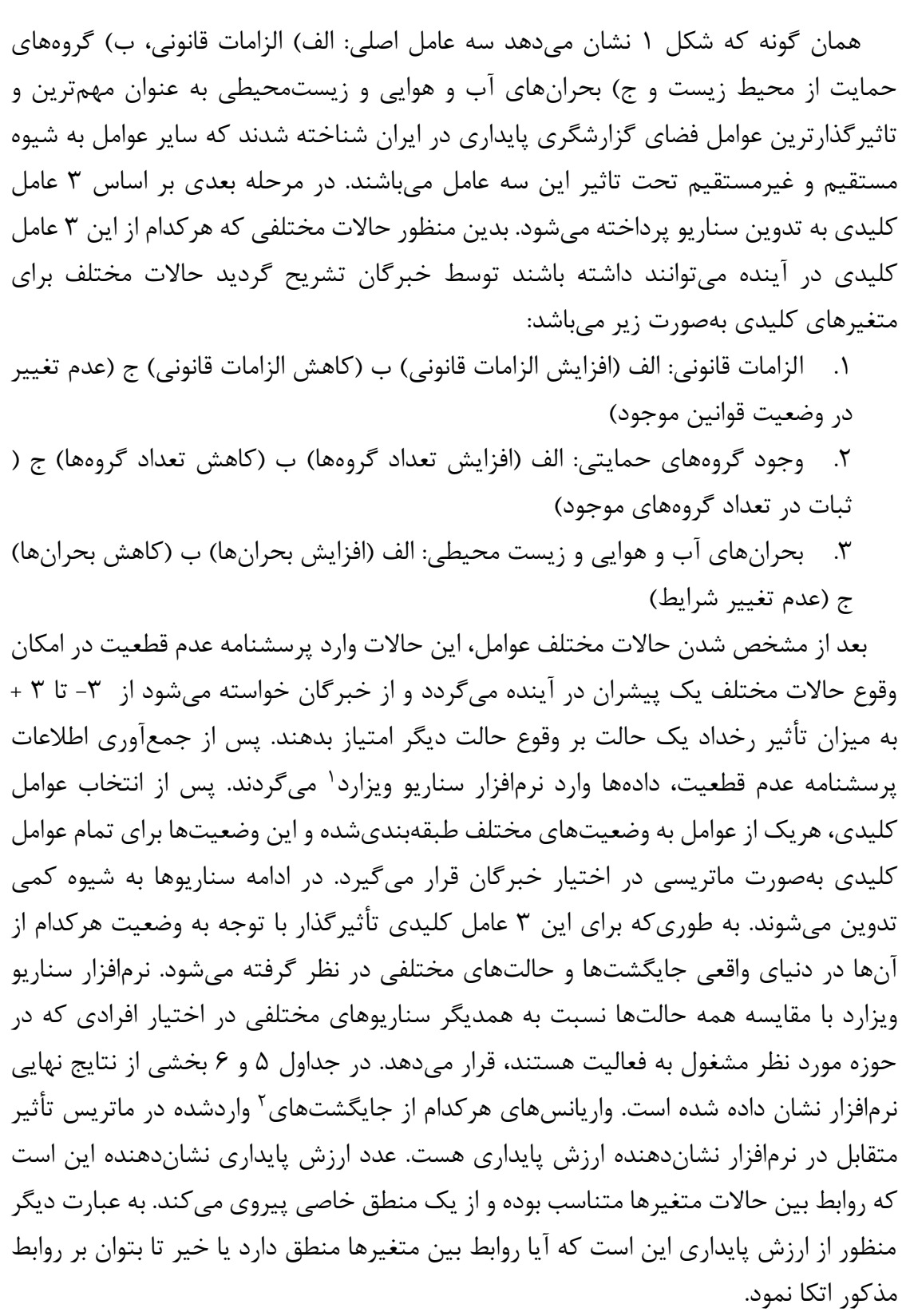

1 -Scenario Wizard

2 - Permutations 
دكتركاشانى يور و همكاران، آينده يزوهى تزارشَّى يايدارى با به كاركيرى رويكرد سناريونويسى

\begin{tabular}{|c|c|c|c|c|c|c|c|c|c|c|}
\hline & & \multicolumn{3}{|c|}{ الزامات قانونى } & \multicolumn{3}{|c|}{ كروه هاى حمايت از محيط } & \multicolumn{3}{|c|}{ بحران هاى آب و هوايى محيطى } \\
\hline & & $\frac{\overline{9}}{\overline{3}}$ & $\frac{b}{3}$ & 3. & $\frac{\overline{2}}{\overline{3}}$ & $\begin{array}{l}y \\
3 \\
3\end{array}$ & 3 & $\frac{\overline{2}}{\overline{3}}$ & $\begin{array}{l}y \\
a \\
\vdots \\
\vdots \\
3\end{array}$ & $\frac{b}{3}$ \\
\hline \multirow{3}{*}{ الزامات قانونى } & افزايش & & & & $r$ & -1 & $\cdot$ & $r$ & $-r$ & 1 \\
\hline & كاهش & & & & $-r$ & $r$ & 1 & $-r$ & $r$ & 1 \\
\hline & ثبات & & & & 1 & -1 & $\cdot$ & $\cdot$ & $\cdot$ & $\cdot$ \\
\hline \multirow{3}{*}{ محريط زمايت از زيست } & افزايش & $-r$ & $r$ & $\cdot$ & & & & $\cdot$ & 1 & $\cdot$ \\
\hline & كاهش & $r$ & -1 & . & & & & $r$ & -1 & $\cdot$ \\
\hline & ثبات & $\cdot$ & 1 & $\cdot$ & & & & $\cdot$ & $\cdot$ & $\cdot$ \\
\hline \multirow{3}{*}{ ز و هران هاى آب و و } & افزايش & $r$ & $-r$ & -1 & $r$ & $-r$ & 1 & & & \\
\hline & عدم تغيير & 1 & $r$ & . & $r$ & $r$ & $\cdot$ & & & \\
\hline & كاهش & $\cdot$ & $\cdot$ & • & - & . & . & & & \\
\hline
\end{tabular}

به عنوان مثال، با رخ دادن افزايش الزامات قانونى احتمال افزايش گرووههاى حمايت از محيط

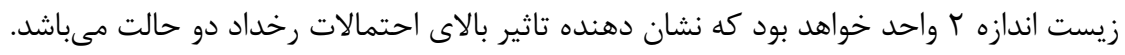

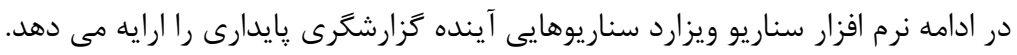
جدول 9: سناريوهاى خروجى نرم افزار

\begin{tabular}{|c|c|}
\hline سناريو شماره r & سناريو شماره ا \\
\hline الزامات قانونى: افزايش الزامات قانونى & الزامات قانونى: كاهش الزامات قانونى \\
\hline كروه هاى حمايت از محيط زيست: & گروه هاى حمايت از محيط زيست: \\
\hline بحران هاى آب و هوايى و زيست محيطى: & بحران هاى آب و هوايى و زيست محيطى: \\
\hline
\end{tabular}

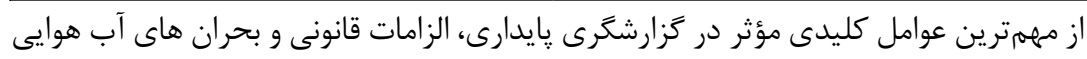

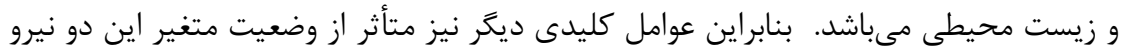

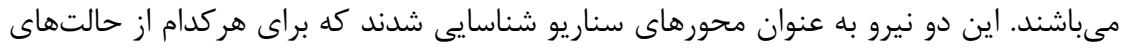

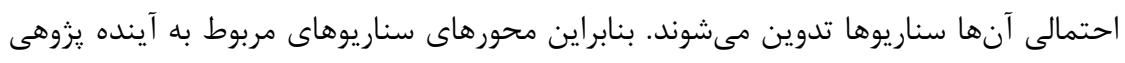

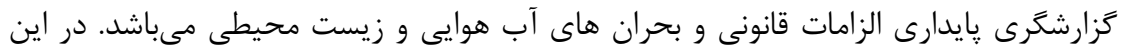

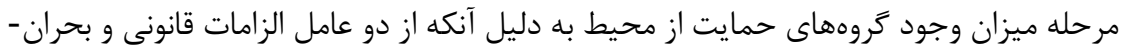

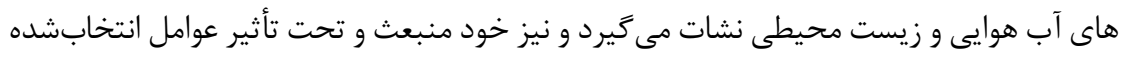


است در منطق سناريو گَنجانده نشد. ضمن اينكه بعد از هماهنكى و مشورت با خبركان مقرر شد كه به صورت شكل r عوامل و محورهاى سناريو انتخاب شوند. • تدوين سناريو •سناريو اول: افزايش بحرانهاى آب و هوايى و زيستمحيطى - افزايش الزامات قانونى (سد

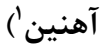
در اين حالت اكر جه بحران هاى آب و هوايى افزايش خواهد يافت ولى نهادهاى قانون كَذار با

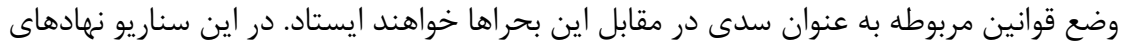

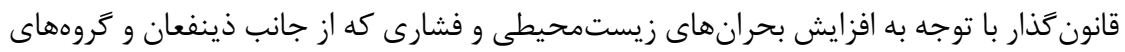

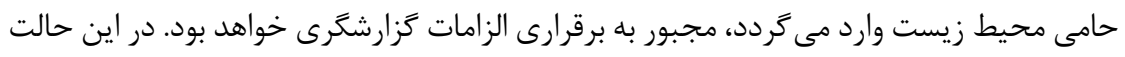

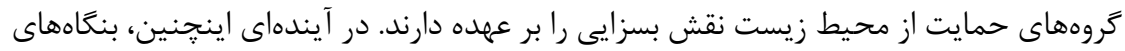

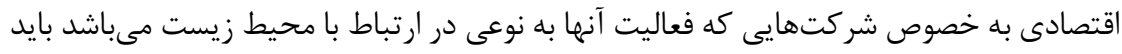

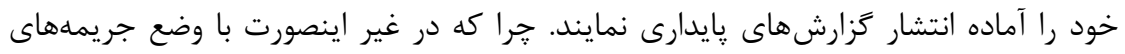

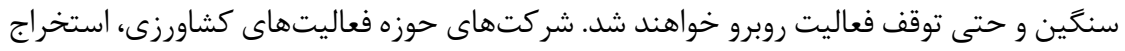

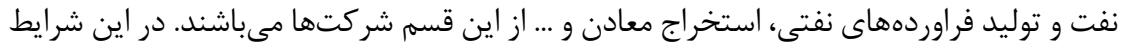

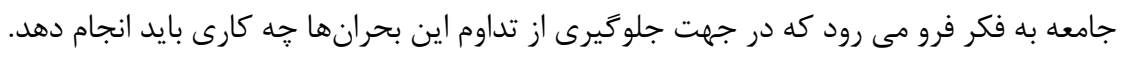

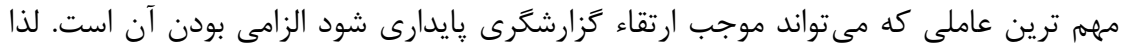

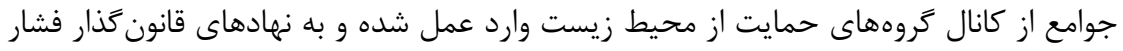

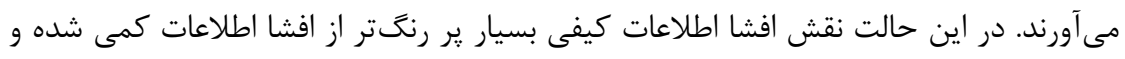

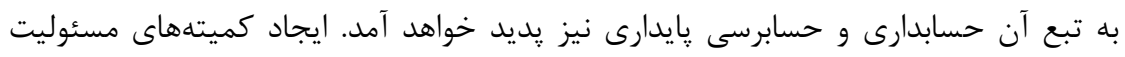

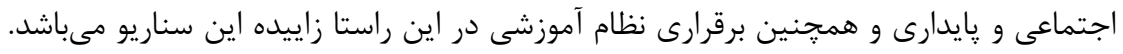

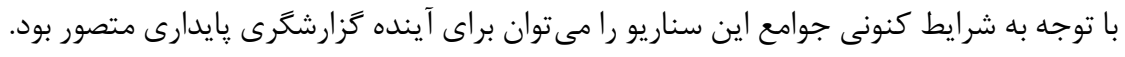

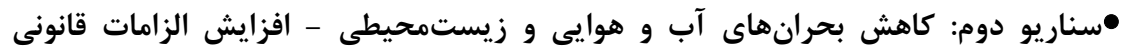
رخداد اين حالت را مىتوان بهشتى براى جامعه در نظر كرفت. در سناريو دوم، كزارشكرى

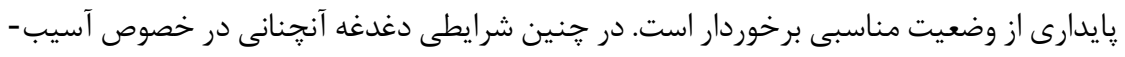

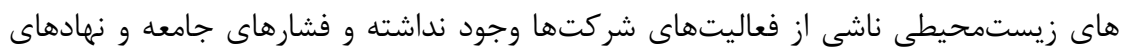

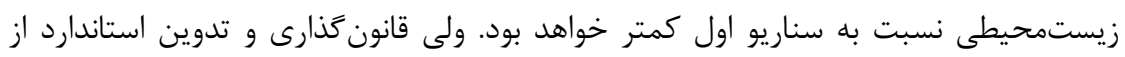

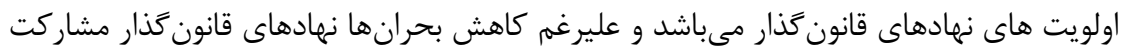

1 -Iron Block

2 - Paradise 
خود را تداوم مىبخشند. در طرف مقابل شركتها ميز بايد خود را در مورد الزامات يوشش داده

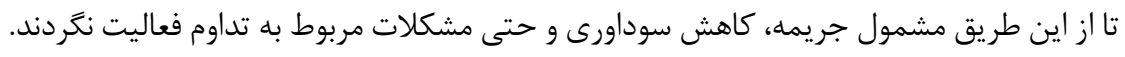

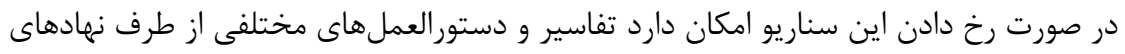

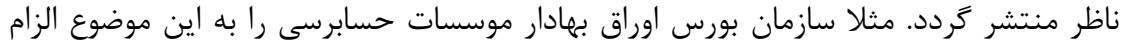

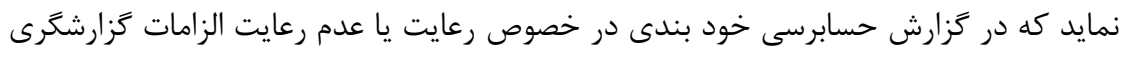

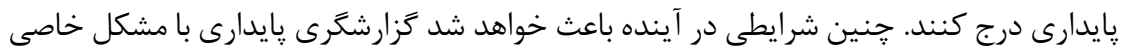

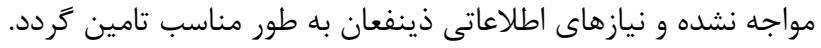

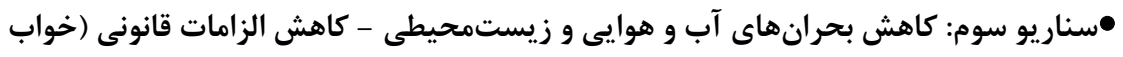
خر توشى' ( در خنين وضعيتى عليرغم عدم آسيب رسانى به آب و هوا و محيط زيست، نهاد قانون كذار نيز

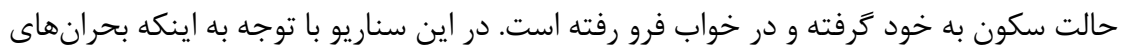

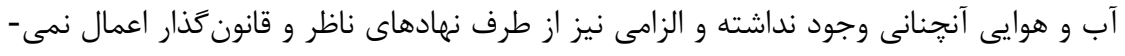

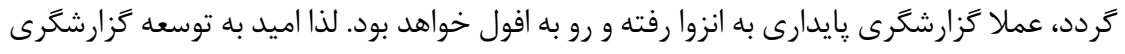

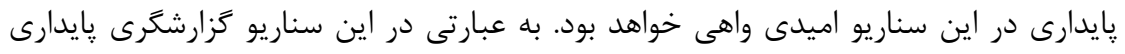

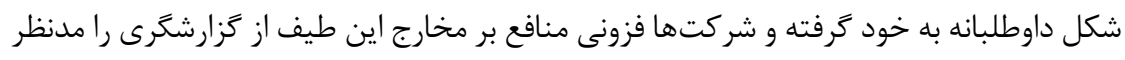

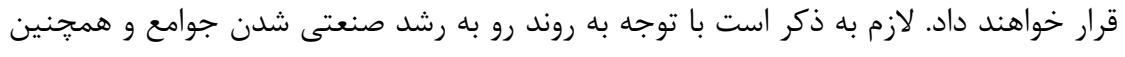

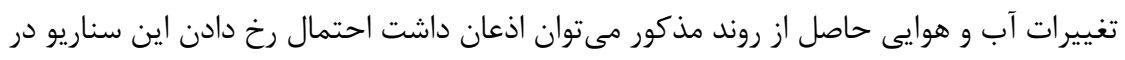

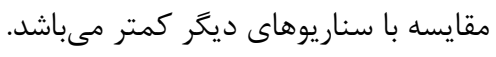

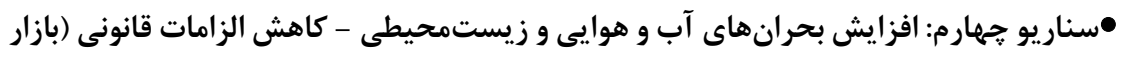

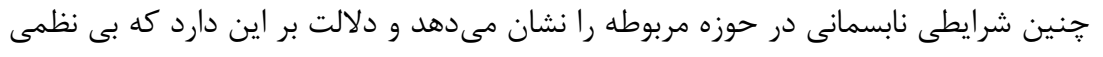

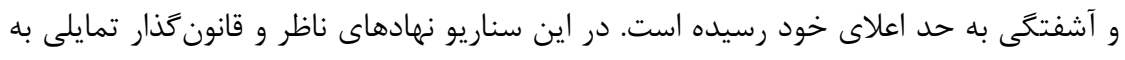

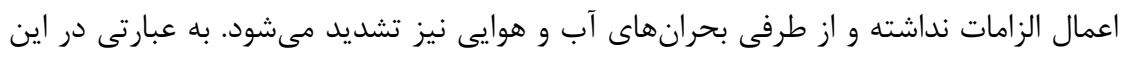

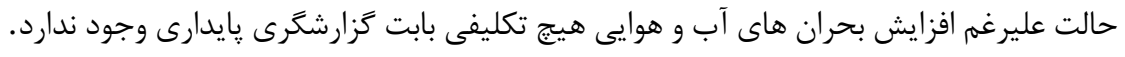

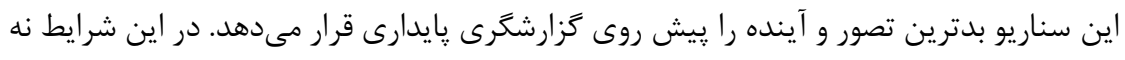

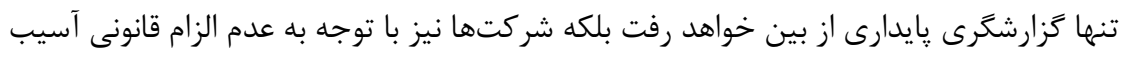

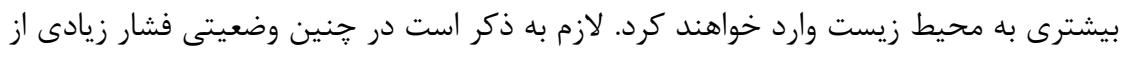

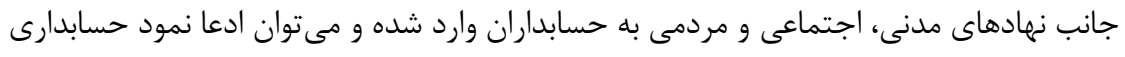

1 Feigned sleep

2 Disarray 
در اين حالت تحت بحران شديدى بوده و مشكلاتى در زمينه گزارشكرى ايجاد خواهد شد. انتظار بر اين است به دليل عدم توجه به كزارشخرى يايدارى در اين سناريو، ارزش بازار سهام شركتها

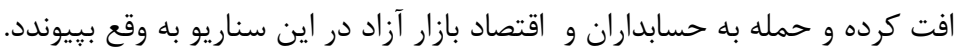

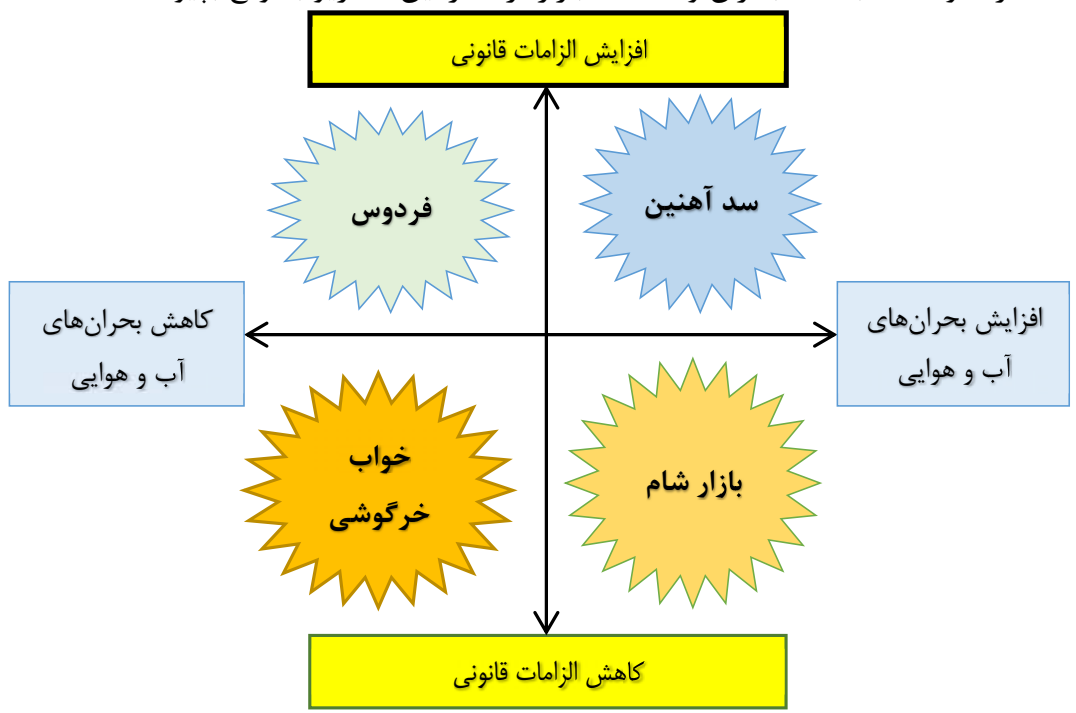

شكل ז: سناريوهاى باوريذير آينده كزارشگرى یايدارى

9-نتيجه گيرى و بحث

نظريه مسئوليت اجتماعى شركتها و گزارشخرى يايدارى، رويكردى متعالى به كسب و كار

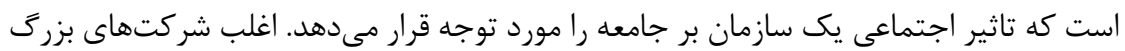
عليرغم ييشرفت در زمينههاى مختلف از جمله زمينههاى اقتصادى و فنى، بخاطر مسائلى كه در

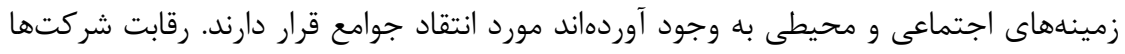

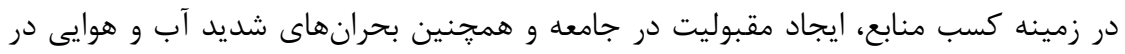
دهdهاى اخير باعث گرديده گَزارشگَى يايدارى از اهميت ويزهاى برخوردار شود. با توجه به

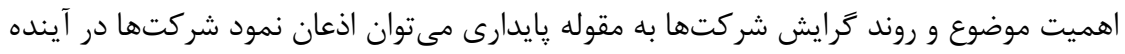

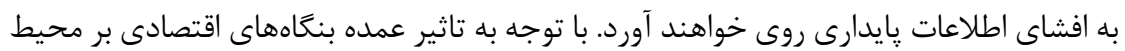
ييرامون و اينكه تداوم زندگى انسانها با محيط زيست گره خورده لذا بايد آمادگى لازم در خصوص ارتقاء اين حوزه مهيا شود. تصميم درباره نحوه مواجهه با اين جالش و عدم قطعيتهاى

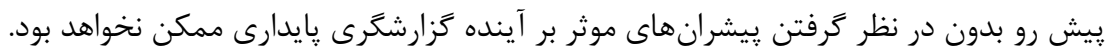




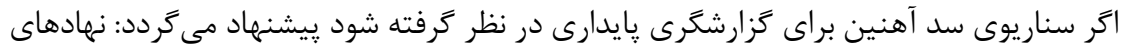

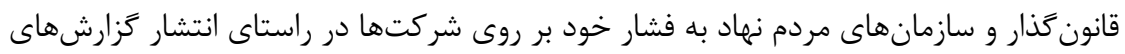

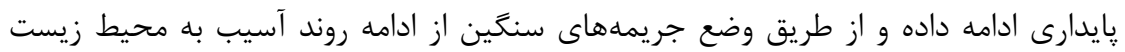

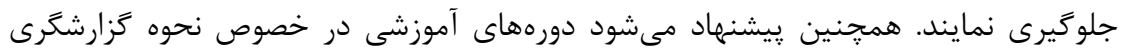

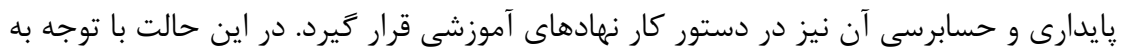

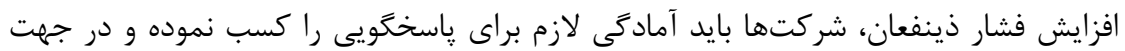

تداوم فعاليت خود كام بردارند. در صورتى كه سناريو فردوس پيش ريش رو باشد وضعيت نسبتا مناسبى در انتظار كزارشكرى

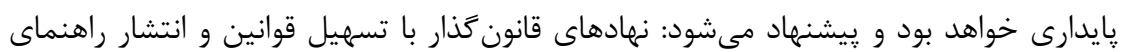

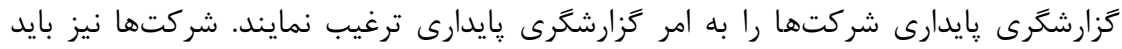

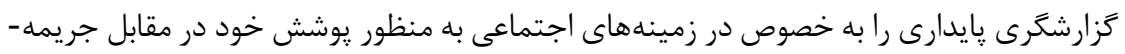

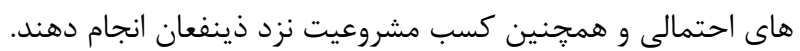
اكر الزامات قانونى و بحرانهاى آب و هوايى كاهش يابد (خواب خركوشى) كَارشكَى يايدارى

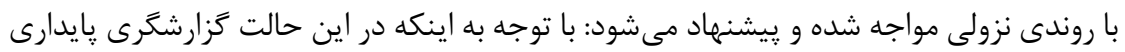

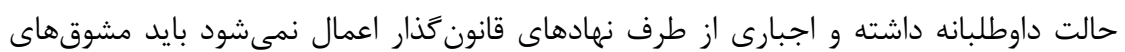

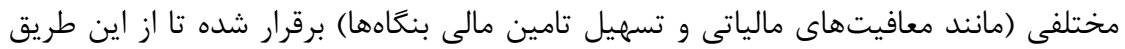
شركتها كزارشكرى يايدارى را انجام دهند.

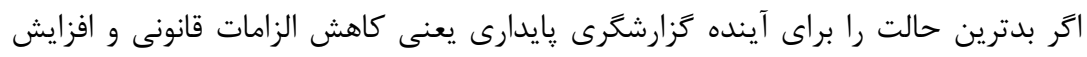

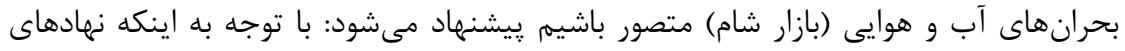

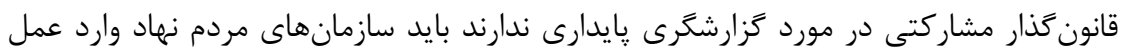

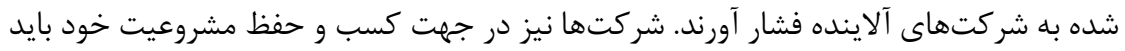

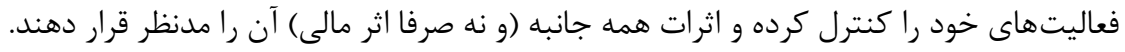

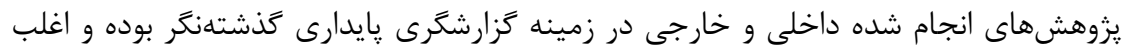

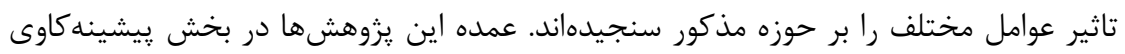

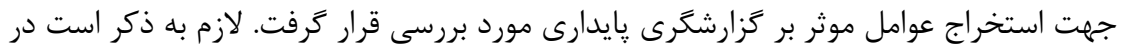

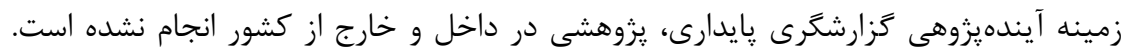

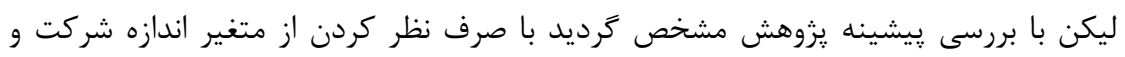

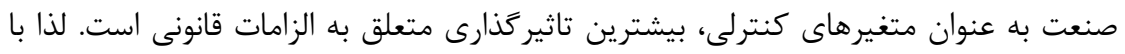

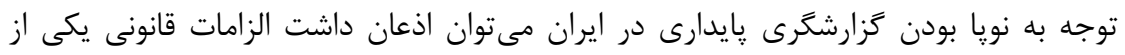

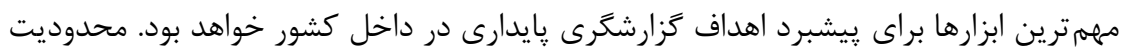


اصلى يزوهش حاضر كمبود خبر گان دانشكاهى و حرفهاى در زمينه گزارشكرى يايدارى با توجه

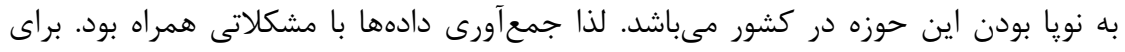

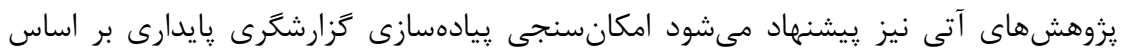

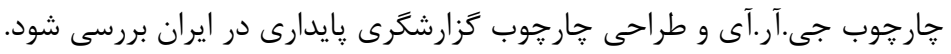

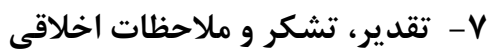
از تمامى افرادى كه با تكميل يرسشنامه هاى تحقيق مار ا در انجام اين يزوهش يارى رساندند بسيار سياسكزاريم.

\section{يبوستها}

يرسشنامه تعيين ميزان اهميت عوامل موثر بر آينده كَزارشَّرى بايدارى

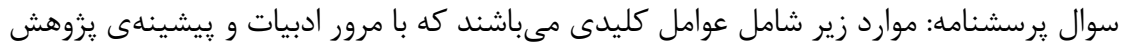

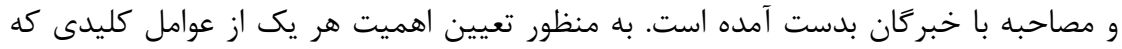

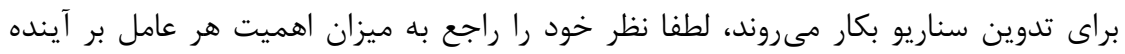

\begin{tabular}{|c|c|c|c|c|c|}
\hline ?:? & $\begin{array}{c}q \\
\vdots \\
3 \\
-1\end{array}$ & $z_{2}$ & $\begin{array}{l}3 \\
3 \\
2\end{array}$ & ميزان اهميت عوامل موثر آينده كزارشگرى يايدارى & .3 \\
\hline & & & & |الزامات قانونى ( ملى يا بين المللى) & 1 \\
\hline & & & & مشوق هاى قانونى ( ملى يا بين المللى) & r \\
\hline & & & & | وجود نكَرش و الزامات اسلامى & $r$ \\
\hline & & & & فشارهاى خارجى(ذينفعان، نهادهاى حرفه اى، رسانه ها و ...) & r \\
\hline & & & & يذيرش در نهادهاى بين المللى و اخذ كواهينامه هاى مربوطه & $\Delta$ \\
\hline & & & & وجود گروه هاى حمايت از محيط زيست & 4 \\
\hline & & & & تكرايش احزاب سياسى كشور به مباحث مسئوليت اجتماعى & $\mathrm{V}$ \\
\hline & & & & |وجود حار جوب مناسب جهت توليد اطلاعات با كيفيت & $\wedge$ \\
\hline & & & & |برَززارى همايش ها و انتشار مجلات تخصصى & 9 \\
\hline & & & & |آموزش آكادميك و حرفه اى افراد در زمينه بِيدارى & $1 \cdot$ \\
\hline & & & & |سياسى شدن مباحث مسئوليت اجتماعى & 11 \\
\hline & & & & تحريم ها & IT \\
\hline
\end{tabular}




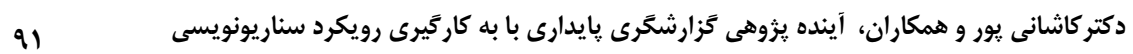

\begin{tabular}{|c|c|c|c|c|c|c|}
\hline $\begin{array}{l}3 \\
3 \\
3 \\
3\end{array}$ & ?) & $\begin{array}{r}: 3 \\
3 \\
-9\end{array}$ & 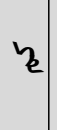 & $\begin{array}{l}3 \\
y \\
z\end{array}$ & ميزان اهميت عوامل موثر آينده كزارشحَى يايدارى & $\hat{\boldsymbol{s}}$ \\
\hline & & & & & |فرهنَ ملى كشور(ذينفع محور بودن كشور) & T \\
\hline & & & & & |اولويت مسائل اقتصادى يا اجتماعى براى جامعه & If \\
\hline & & & & & |اولويت مسائل اقتصادى يا اجتماعى براى دولت & 10 \\
\hline & & & & & |دولتى يا خصوصى بودن اقتصاد & 19 \\
\hline & & & & & |شاخص هاى اقتصادى كشور & IV \\
\hline & & & & & |توجه به حقوق بشر در آينده & 11 \\
\hline & & & & & سطح توسعه و رفاه اجتماعى و آكاهى افراد از حقوق خود & 19 \\
\hline & & & & & |جهانى شدن اقتصاد & $r \cdot$ \\
\hline & & & & & كارايى بازار سرمايه & 41 \\
\hline & & & & & بحران هاى آب و هوايى و زيست محيطى & tr \\
\hline & & & & & |ورود تكنولوزى و فناورى اطلاعات به حرفه & r \\
\hline & & & & & |استقلال هيات مديره & rF \\
\hline & & & & & تنوع جنسيتى هيات مديره & ta \\
\hline & & & & & |وجود كميته هاى مسئوليت اجتماعى و يايدارى & te \\
\hline & & & & & |ويزگى هاى كميته حسابرسى & tr \\
\hline & & & & & 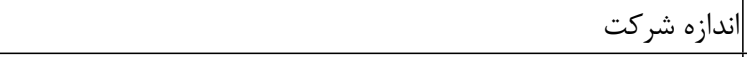 & rA \\
\hline & & & & & شهرت شركت & 49 \\
\hline & & & & & 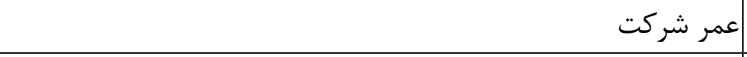 & r. \\
\hline & & & & & فرهنَ سازمانى & 更 \\
\hline & & & & & 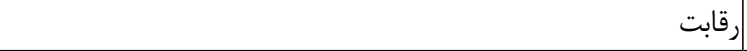 & tr \\
\hline & & & & & |شاخص هاى عملكردى شركت & سب \\
\hline & & & & & 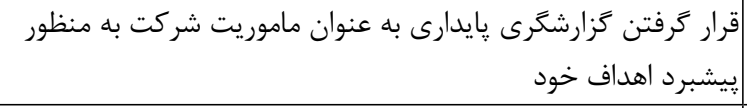 & re \\
\hline & & & & & نحوه تامين مالى شركت (استفاده از بدهى يا افزايش سرمايه) & ra \\
\hline & & & & & |كيفيت تزارشكرى مالى & re \\
\hline & & & & & نوع صنعت & re \\
\hline & & & & & | (دسترسى به منابع مالى & rی \\
\hline & & & & & |دسترسى منابع انسانى متخصص & rq \\
\hline
\end{tabular}


دو فصلنامه حسابدارى ارزشى و رفتارى، سال ينجم، شماره دهم، پِاييز و زمستان وجسا

\begin{tabular}{|c|c|c|c|c|c|c|}
\hline 苛: & ?" & $\begin{array}{l}9 \\
3 \\
3 \\
-1\end{array}$ & $y_{2}$ & $\begin{array}{l}3 ; \\
3 \\
z_{k}\end{array}$ & ميزان اهميت عوامل موثر آينده كَزارشكَى يايدارى & 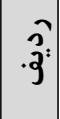 \\
\hline & & & & & | وضعيت معيشتى محل فعاليت شركت & $r \cdot$ \\
\hline & & & & & 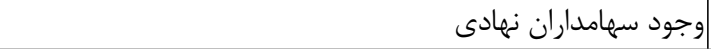 & +1 \\
\hline & & & & & 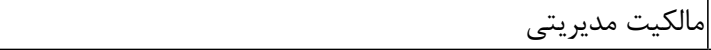 & Ft \\
\hline & & & & & |ويزگى هاى رفتارى مديران (وجدان و اعتماد به نفس مديران) & Fr \\
\hline & & & & & | انش و نكَرش مديران شركت & fr \\
\hline & & & & & |تداوم مديريت مديرعامل و دوكانكى وظيفه وى & is \\
\hline
\end{tabular}

يرسشنامه تحليل اثرات متقابل عوامل موثر بر آينده كَارشگرى بايدارى

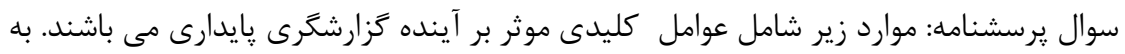

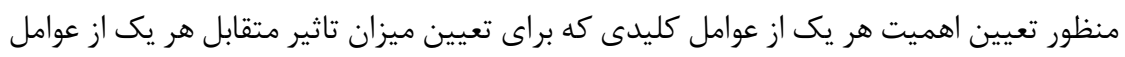

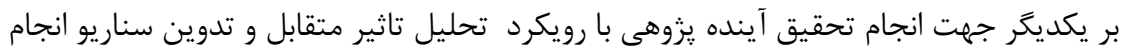

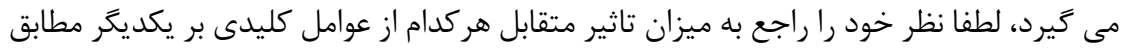
جدول ذيل مشخص نماييد.

\begin{tabular}{|c|c|c|c|}
\hline تاثير زياد & تاثير متوسط & تاثير ضعيف & بدون تاثير \\
\hline$r$ & $r$ & 1 & . \\
\hline
\end{tabular}




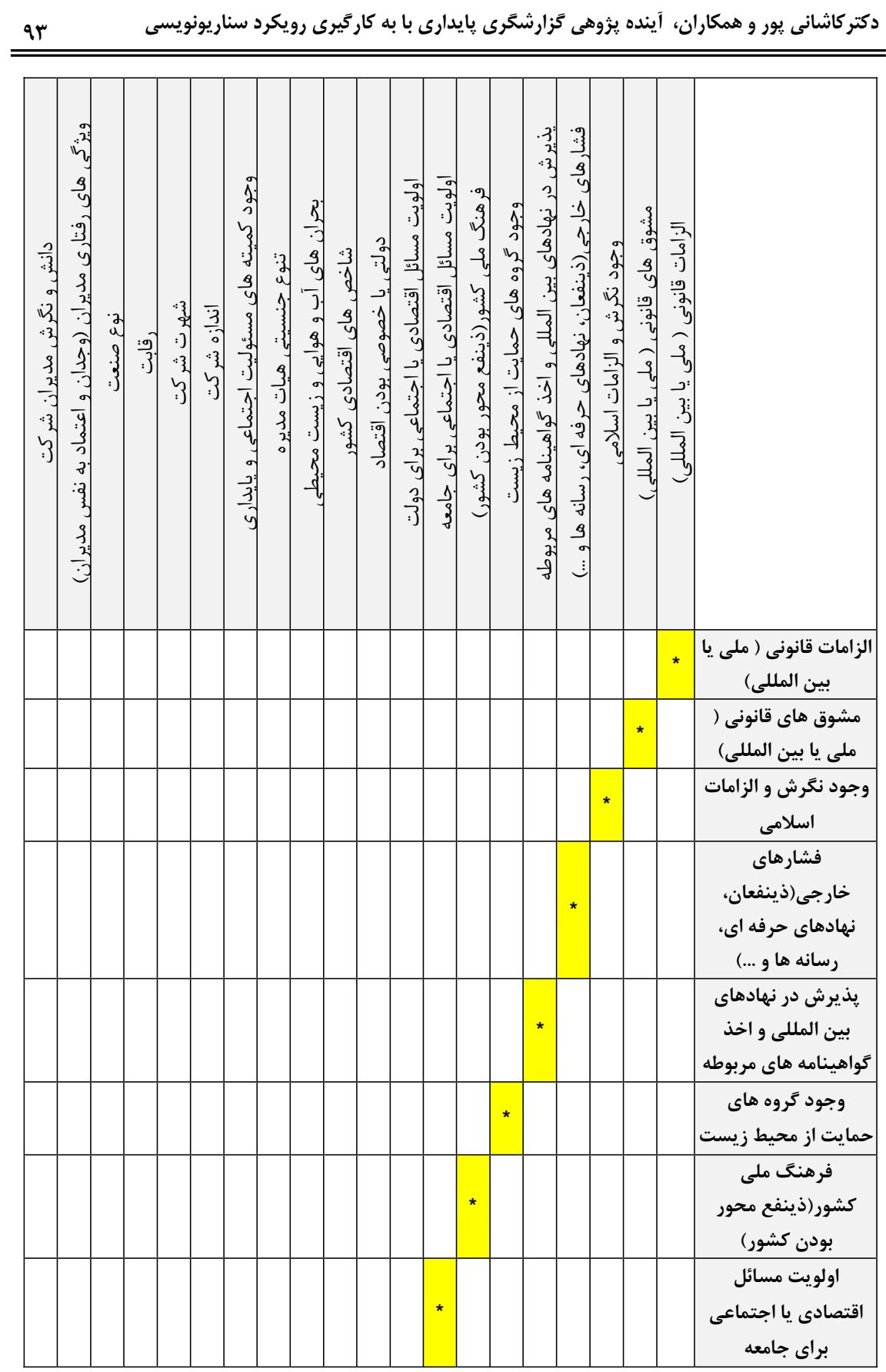


دو فصلنامه حسابدارى ارزشى و رفتارى، سال ينجم، شماره دهم، پِاييز و زمستان وجسا

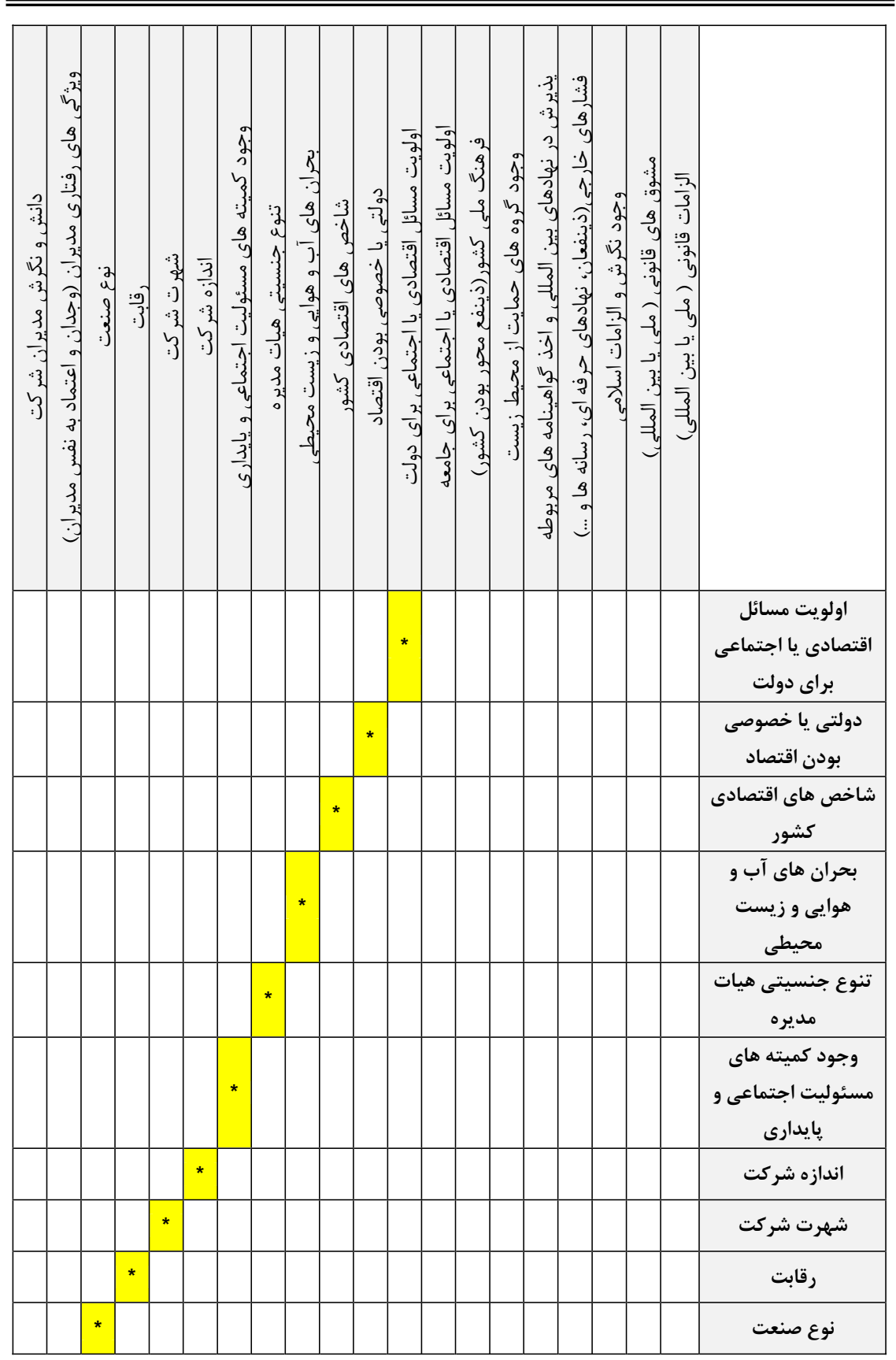




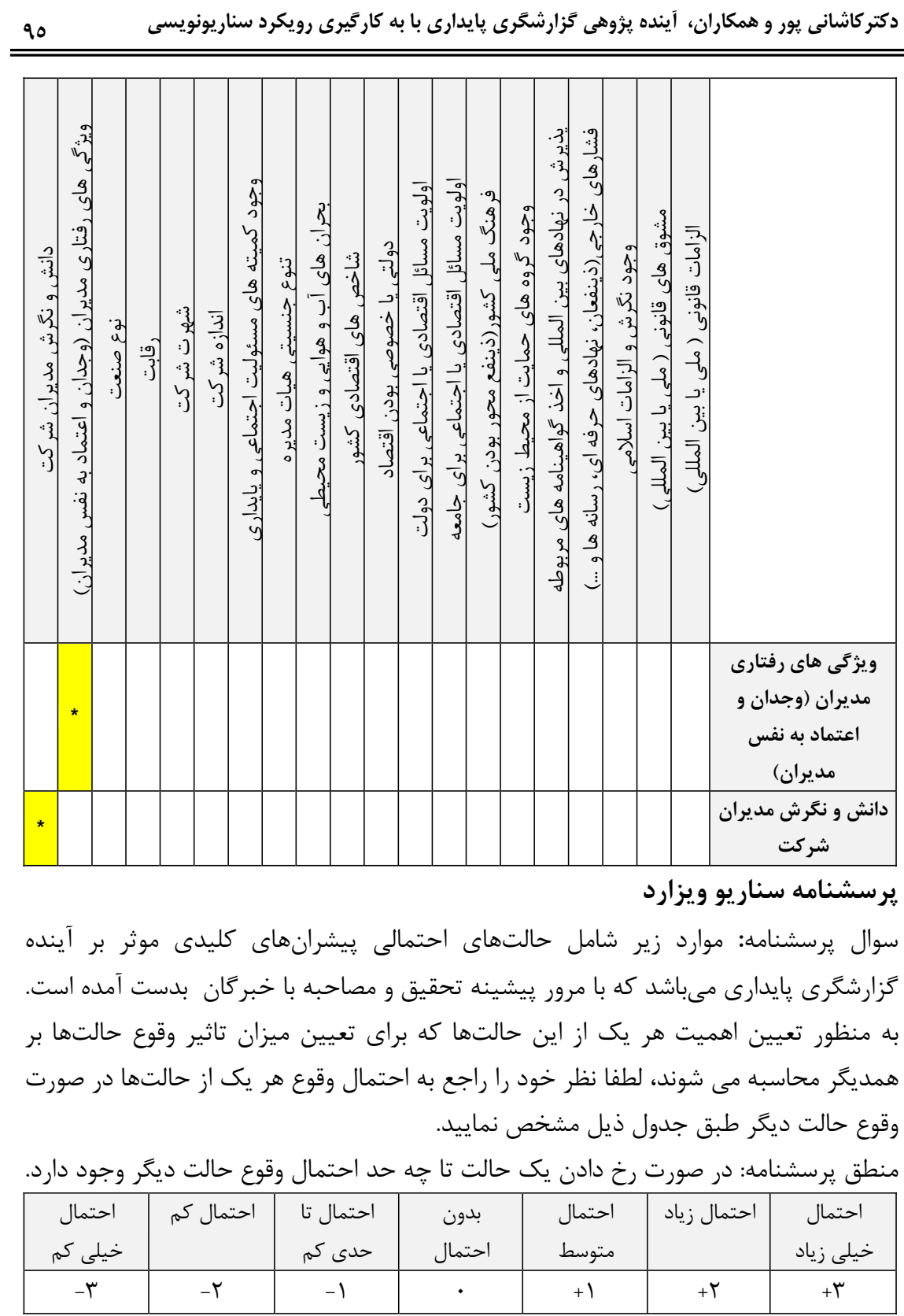


دو فصلنامه حسابدارى ارزشى و رفتارى، سال ينجم، شماره دهم، پِاييز و زمستان وجسا

\begin{tabular}{|c|c|c|c|c|c|c|c|c|c|c|}
\hline \multicolumn{3}{|c|}{ بحران هاى آب و هوايى } & \multicolumn{3}{|c|}{ كروه هاى حمايت } & \multicolumn{3}{|c|}{ الزامات قانونى } & & \\
\hline كاهش & تغيير & افزايش & ثبات & كاهش & افزايش & ثبات & كاهش & افزايش & & \\
\hline & & & & & & & & & افزايش & \multirow{3}{*}{ الزامات قانونى } \\
\hline & & & & & & & & & كاهش & \\
\hline & & & & & & & & & ثبات & \\
\hline & & & & & & & & & افزايش & \multirow{3}{*}{ حمايت از محيط زيط } \\
\hline & & & & & & & & & كاهش & \\
\hline & & & & & & & & & ثبات & \\
\hline & & & & & & & & & افزايش & \multirow{3}{*}{ ز و هران هاى آب } \\
\hline & & & & & & & & & عدم تغيير & \\
\hline & & & & & & & & & كاهش & \\
\hline
\end{tabular}

اكبرى، محسن؛ قاسمى شمس، معصومه؛ هوشمند، فاطمه. (ه9 (1)، بررسى تاثير اعتمادبه نفس

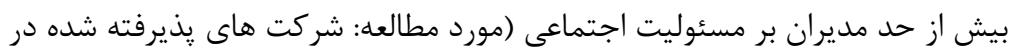

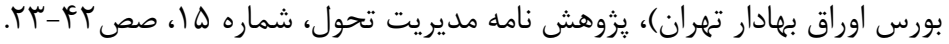

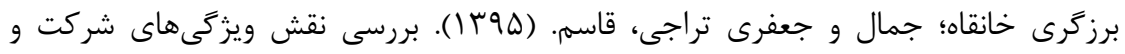

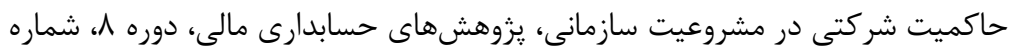

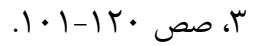

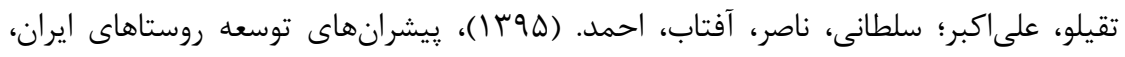

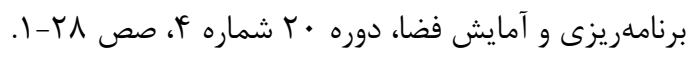

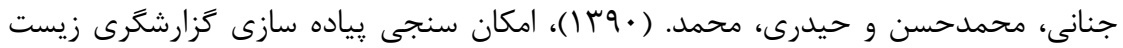

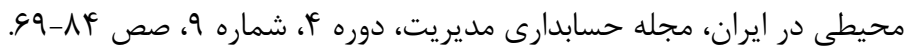

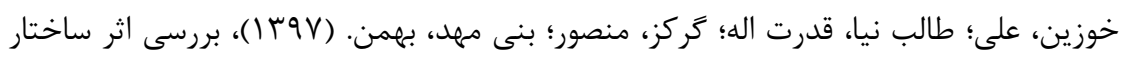

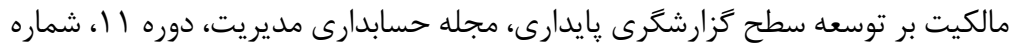

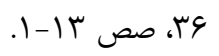

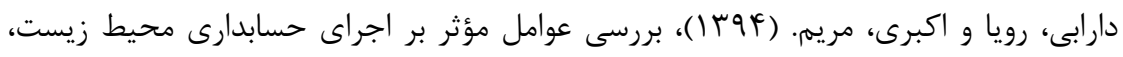

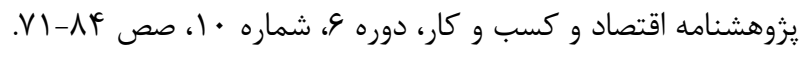


رشيد ارده، حبيب اله و خزايى، سعيد. (ه9 (1)، تحليل كلان روندهاى مؤثر بر آيندة بازار صنعت

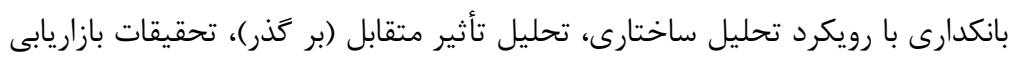

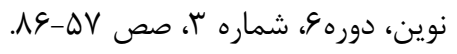

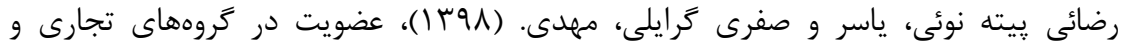

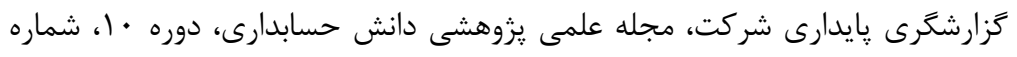

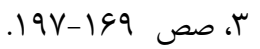

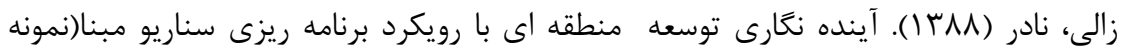

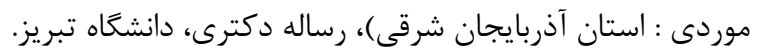

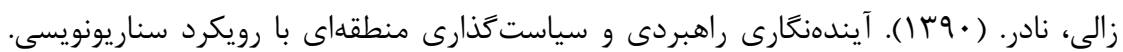

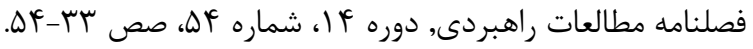

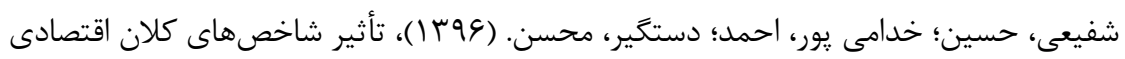

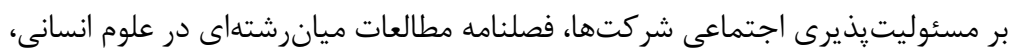

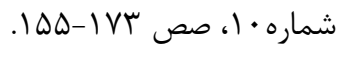

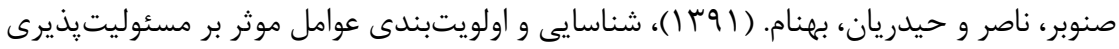

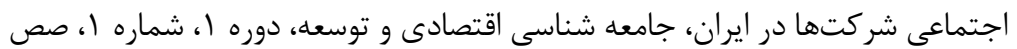

$$
. \vee 1-19
$$

طالب نيا، قدرت اله؛ رجب درى، حسين؛ خانى ذلان، امير رضا. (Y IY )، بررسى عوامل مؤثر بر

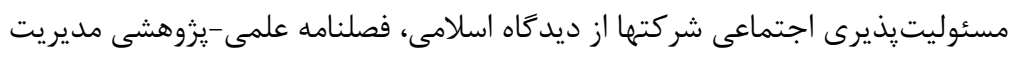

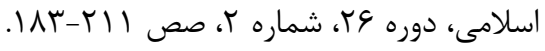
عالمشاه، سيدامين. (سو ( )، بررسى عوامل مؤثر در اتخاذ روشهاى حسابدارى مديريت زيست

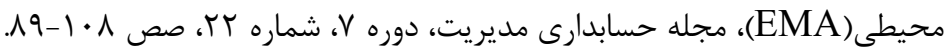

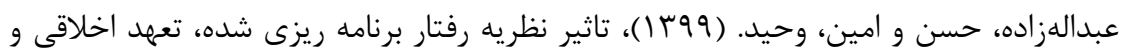
ادراك ريسك بر تمايل به حسابدارى و گزارشَّىى پايدارى شركتى، فصلنامه حسابدارى ارزشى و رفتارى، دوره ه، شماره 9، مقالات آماده انتشار.

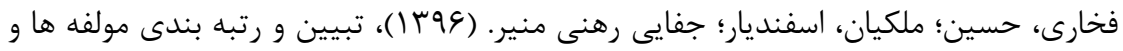
شاخص هاى گزارشگرى زيست محيطى، اجتماعى و راهبرى شركتى به روش تحليل

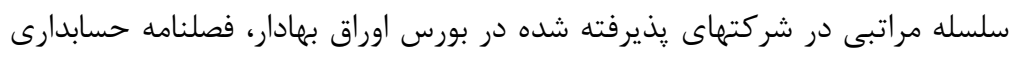

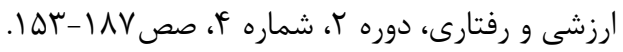




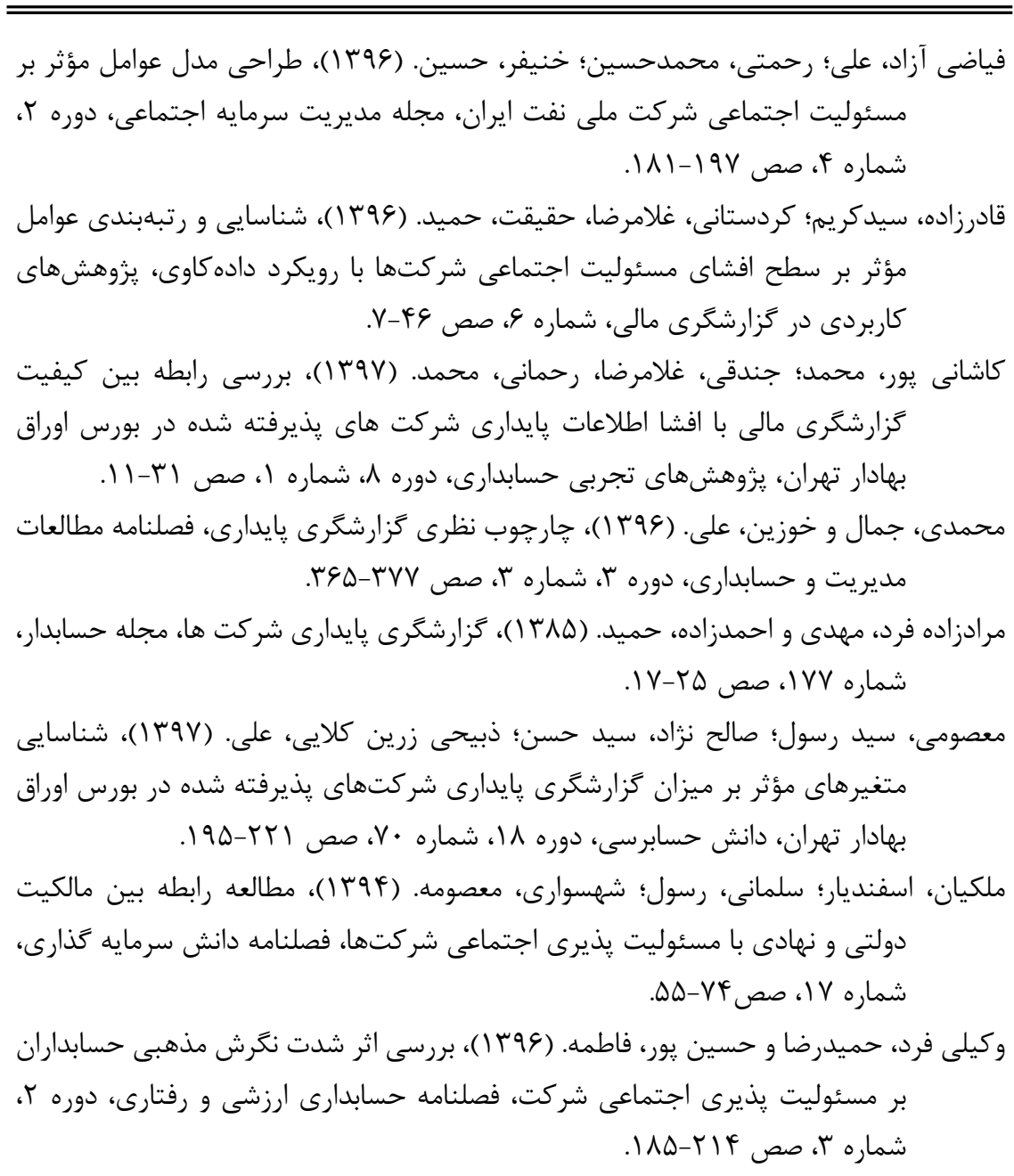

Adnan, S., D, Hay, \& S, Chris. 2018. The Influence of Culture and Corporate Governance on Corporate Social Responsibility Disclosure: A Cross Country Analysis. Journal of Cleaner Production, 198: 820-832.

Akin, A., \& I, Yilmaz. 2016. Drivers of Corporate Social Responsibility Disclosures: Evidence from Turkish Banking Sector. Procedia Economics and Finance, 38: 2-7.

Ali, W., J, Frynas, \& M, Zeeshan. 2017. Determinants of Corporate Social Responsibility (CSR) Disclosure in Developed and Developing Countries: A Literature Review. Corporate Social Responsibility and Environmental Management, 24 (4): 273-294. 
دكتر كاشانى يور و همكاران، آينده بزوهى كزارشكَرى بايدارى با به كارَّيرى رويكرد سناريونويسى

Al-Shaer, H., \& M, Zaman. 2016. Board Gender Diversity and Sustainability Reporting Quality. Journal of Contemporary Accounting \& Economics, 12 (3): 210-222.

Aman, Z., \& I, Sharifah. 2017. The Determinants of Corporate Sustainability Reporting: Malaysian Evidence, The 4th International Conference on Management and Muamalah, (ICoMM 2017) e-ISBN: 978-967-212215-9.

Cao, F., S, Peng, \& Y, Kangtao. 2019. Multiple large Shareholders and Corporate Social Responsibility Reporting. Emerging Markets Review, 38: 287-309.

Chen, W., G, Zhou, \& Z, Xindong. 2019. CEO Tenure and Corporate Social Responsibility Performance. Journal of Business Research, 95: 292302.

De Villiers, C. \& Maroun, W. 2018. The Future of Sustainability Accounting and Integrated Reporting, In De Villiers, C \& Maroun, W. (Eds.) Sustainability accounting and integrated reporting, Routledge: Abingdon, UK.

Deegan, C., \& B, Gordon. 2012. A Study of the Environmental Disclosure Practices of Australian Corporations. Accounting and Business Research, 26 (3): 187-199.

Dienes, D., R, Sassen, \& J, Fischer. 2016. What are the Drivers of Sustainability Reporting? A Systematic Review. Sustainability Accounting, Management and Policy Journal, 7 (2): 154-189.

Dyduch, J., \& J, Krasodomska. 2017. Determinants of Corporate Social Responsibility Disclosure: An Empirical Study of Polish Listed Companies. Econ Papers, 9 (11): 1-24.

Fifka, M. 2011. Corporate Responsibility Reporting and its Determinants in Comparative Perspective - a Review of the Empirical Literature and a Meta-analysis. Business Strategy and the Environment, 22 (1): 135 .

Habek, P., \& R, Wolniak. 2015. Factors Influencing the Development of CSR Reporting Practices: Experts' versus Preparers' Points of View. Inzinerine Ekonomika-Engineering Economics, 26 (5): 560-570.

Hahn, R., \& M, Kuhnen. 2013. Determinants of Sustainability Reporting: a Review of Results, Trends, Theory and Opportunities in an Expanding Field of Research. Journal of Cleaner Production, 59: 521.

Hang, Ph. 2017. Factors Affecting Corporate Social Responsibility (CSR): A Case of Commercial Banks in Ho Chi Minh City. Auditing and Finance Research, 5 (4): 43-53. 
Jensen, C., \& N, Berg. 2011. Determinants of Traditional Sustainability Reporting Versus Integrated Reporting. An Institutionalist Approach. Business Strategy and the Environment, 21 (5): 299-316.

Kilıç, M., \& C, Kuzey. 2017. Factors Influencing Sustainability Reporting: Evidence from Turkey. Available at SSRN: https://ssrn.com/abstract=3098812.

Kim, H., T, Kim, Y, Kim, \& K, Park. 2019. Do long-term Institutional Investors Promote Corporate Social Responsibility Activities?, Journal of Banking \& Finance, 101: 256-269.

Kuzey, C., \& A, Uyar. 2017. Determinants of Sustainability Reporting and its Impact on Firm Value: Evidence from the Emerging Market of Turkey. Journal of Cleaner Production, 143: 27-39.

Kwakye, T., E, Welbeck, Y, Owusu, \& K, Anokye. 2018. Determinants of Intention to Engage in Sustainability Accounting \& Reporting (SAR): The Perspective of Professional Accountants. International Journal of Corporate Social Responsibility: CSR, Sustainabilitiy, Ethics and Governance, 3 (11): 1-13.

Laskar, N. 2019. Does Sustainability Reporting Enhance Firms Profitability? A Study on Select Companies from India and South Korea. Indian Journal of Corporate Governance, 12 (1): 2-20.

Li, N., A, Toppinen, A, Tuppura, \& K, Puumalainen. 2011. Determinants of Sustainability Disclosure in the Global Forest Industry. EJBO Electronic Journal of Business Ethics and Organization Studies, 16 (1): 33-40.

Moon, J. 2004. Government as a Driver of Corporate Social Responsibility. ICCSR Research, 20: 1-27.

Olthuis, B, \& K, Oever. 2020. The board of directors and CSR: How does ideological diversity on the board impact CSR?. Journal of Cleaner Production, 251, 1-10.

Park, B., \& A, Cave. 2018. Corporate Social Responsibility in International Joint Ventures: Empirical Examinations in South Korea. International Business Review, 27 (6): 1213-1228.

Peters, G., \& R, Andrea. 2015. The Association between Sustainability Governance Characteristics and the Assurance of Corporate Sustainability Reports. A Journal of Practice \& Theory, 34 (1): 163198.

Ranjani, M. 2014. Key Drivers of Sustainability Reporting (a Study in Indian Perspective). Management \& Change, 18 (1): 73-90.

Rezaee, Z. 2016. Business sustainability research: A theoretical and integrated perspective. Journal of Accounting Literature, 36, 48-64.

Rezaee, Z., M, Alipour., O, Faraji., N, Jamshidi, \& M, Ghanbarim. 2020. Environmental Disclosure Quality and Risk-Taking: Moderating 
دكتر كاشانى يور و همكاران، آينده يزوهى تزارشكَى يايدارى با به كارَيرى رويكرد سناريونويسى

Effect of Corporate Governance, Sustainability Accounting, Management and Policy Journal, Article in Press, Forthcomming 2020.

Robinson, R., I, Vodovoz., K, Sullivan., \& J, Burns. 2019. Sustainability disclosure goes mainstream, Deloitte Heads Up newsletters, 26(21): 1- 8 .

Rosati, F., \& L, Faria, L. 2019. Addressing the SDGs in Sustainability Reports: The Relationship with Institutional Factors. Journal of Cleaner Production, 215: 1312-1326.

Sanchez, I., S, Fernandez, \& M, Ferrero. 2019. Female Directors and Dmpression Management in Sustainability Reporting. International Business Review, 28 (2): 359-374.

Selvanathan, P. 2012. Identifying the Key Determinants of Effective Corporate Sustainability Reporting by Malaysian government-linked Companies. DBA thesis, Southern Cross University, Lismore, NSW.

Shi, G., J, Sun, L, Zhang, \& Y, Jin. 2017. Corporate Social Responsibility and Geographic Dispersion. Journal of Accounting and Public Policy, 36 (6): 417-428.

Toni, A., A, Heidi, \& T, Anu. 2012. Towards Long-term Foresight for Transport: Envisioning the Finnish Transport System in 2100. Journal of Foresight, 14 (3): 191-206.

Valiente, J., G, Concepcion, \& S, Manuel. 2017. Corporate Social Responsibility Drivers and Barriers According to Managers' Perception; Evidence from Spanish Firms. Sustainability, MDPI, Open Access Journal, 9 (10): 1-24.

Visscher, D. 2016. Determinants of External Assurance of Sustainability Reporting: A European Analysis, Master Accounting and Control thesis, Radboud University Nijmegen.

Wuttichindanon, S. 2017. Corporate Social Responsibility Disclosure Choices of Report and its Determinants: Empirical Evidence from Firms Listed on the Stock Exchange of Thailand. Kasetsart Journal of Social Sciences, 38 (2): 156-169.

Yanez, S., A, Uruburu, A, Moreno, \& J, Lumbreras. 2019. The sustainability report as an essential tool for the holistic and strategic vision of higher education institutions. Journal of Cleaner Production, 207, 57-66 